\title{
Lower and Middle Triassic foraminifera from the Eros Limestone, Hydra Island, Greece
}

\author{
R. RETTORI', L. ANGIOLINI ${ }^{2}$ \& G. MUTTONI \\ ${ }^{1}$ Dipartimento di Scienze della Terra dell'Università degli Studi di Perugia, 06100 Perugia, Italy \\ ${ }^{2}$ Dipartimento di Scienze della Terra dell'Università degli Studi di Milano, 20133 Milano, Italy
}

\begin{abstract}
The systematics and stratigraphic ranges (constrained by conodont dating) of abundant and well preserved foraminiferal faunas from six sections in the Lower and Middle Triassic Eros Limestone of central and western Hydra (Argolis Peninsula, Greece) are described. A joint analysis of the conodonts, foraminifera and bivalves has enabled the Scythian and Anisian stages to be recognized with some certainty within the Eros Limestone carbonate platform. The foraminifera have affinities with those of many other Tethyan localities, in particular the Dinarides, Balkans, Carpathians and the Southern Alps. J. Micropalaeontol. 13(1): 25-46, September 1994.
\end{abstract}

\section{INTRODUCTION}

The small Island of Hydra is located in the Aegean just to the south of the Argolis Peninsula (Peloponnesus, Greece) (Fig. 1). Its sedimentary succession ranges from Permian to Jurassic in age.

Triassic rocks have been studied by Renz (1906-31), Wendt (1973), Römermann (1968), Römermann et al. (1981), Schäfer \& Senowbari-Daryan (1984) and by Angiolini et al. (1992). From the base, they consist of the Aghios Nikolaos Formation, the Eros Limestone, the Han Bulog Limestone, the Quartz Keratophyric Tuffs and part of the Adhami Limestone and Pantokrator Limestone (Fig. 2). The Lower and Middle Triassic portion of this succession, constituting the carbonate platform of the Eros Limestone, was initially studied by Römermann (1968-9), Römermann et al. (1981) and subsequently has seen extensive work by Angiolini et al. (1992).

This paper seeks to improve our knowledge of the biostratigraphy of the Eros Limestone by providing new important data on the distribution of some of the Triassic foraminifera, calibrated to the standard stages and substages of the Triassic, using mainly conodonts.

\section{GEOLOGICAL SETTING}

The island of Hydra belongs to the Subpelagonian Zone, defined as a passive continental margin succession deposited on the western part of the Pelagonian Block, according to Jacobshagen et al. (1977; 1989 pers. comm.). Both Subpelagonian and Pelagonian zones are part of the Internal Hellenides (Fig. 1).

The sedimentary sequence of Hydra is arranged in four major south vergent thrust sheets, dissected by transcurrent faults (Fig. 3). The Eros Limestone constitutes the backbone of the southern thrust sheet and part of the O. Zakoni and Kutali thrust sheets (nomenclature after Angiolini et al. 1992). The areal distribution of the Eros Limestone, together with the schematic tectonic setting of the island, are shown in Fig. 3.

\section{THE EROS LIMESTONE}

The Eros Limestone was named by Römermann (1968) after the highest mountain of Hydra (Mount Eros, $589 \mathrm{~m}$ ). It constitutes a well-developed carbonate platform, 600-670 m thick, of Early to Middle Triassic age. It overlies the Aghios Nikolaos Formation (quarzarenites; Early Triassic) or directly the Episkopi Limestone (bioclastic limestone; Late Permian) and is bounded at the top by the Han Bulog Limestone (red nodular limestone; latest Pelsonian-latest Illyrian/Ladinian) or directly by the Adhami Limestone (grey cherty limestone; Early Ladinian-Late Triassic).

Angiolini et al. (1992) subdivided the Eros Limestone on the basis of microfacies and field analyses. The present work improves these analyses. Six stratigraphic sections are presented here (Fig. 4): sections 1, 3, 4, 5 and 6 were sampled by the present authors, section 2 by $M$. Richards (University of Lausanne). We have divided the Eros Limestone into four subunits: the lower lithozone, the Eros Limestone sensu stricto, the dark member and the upper lithozone.

The lower lithozone (25-100 m thick) constitutes the base of the Eros platform (Fig. 2) and consists of grey oolitic limestone with a variable content of quartz grains; yellow siltstone interbeds with species of the bivalve genera Unionites and Eumorphotis of Spathian age (determination by R. Posenato, University of Ferrara) are also present.

There is a gradual transition from this lithozone into the overlying Eros Limestone sensu stricto $(500-600 \mathrm{~m}$ thick), itself subdivided into four main microfacies, from the base to top (Fig. 5): microfacies 1, consisting of oolitic grainstones and packstones with rare bioclasts (gastropods, echinoderms, ostracods, bivalves and foraminifera). It is locally (Aghios Marina) overlain by microfacies 2, consisting of mudstones and wackestones with oolites, intraclasts, peloids and rare bioclasts, or more commonly, it is overlain by microfacies 3, made up of packstones and wackestones with cements and bioclasts (foraminifera, bivalves, ostracods, echinoderms, gastropods, algae, stromatolites and prob- 


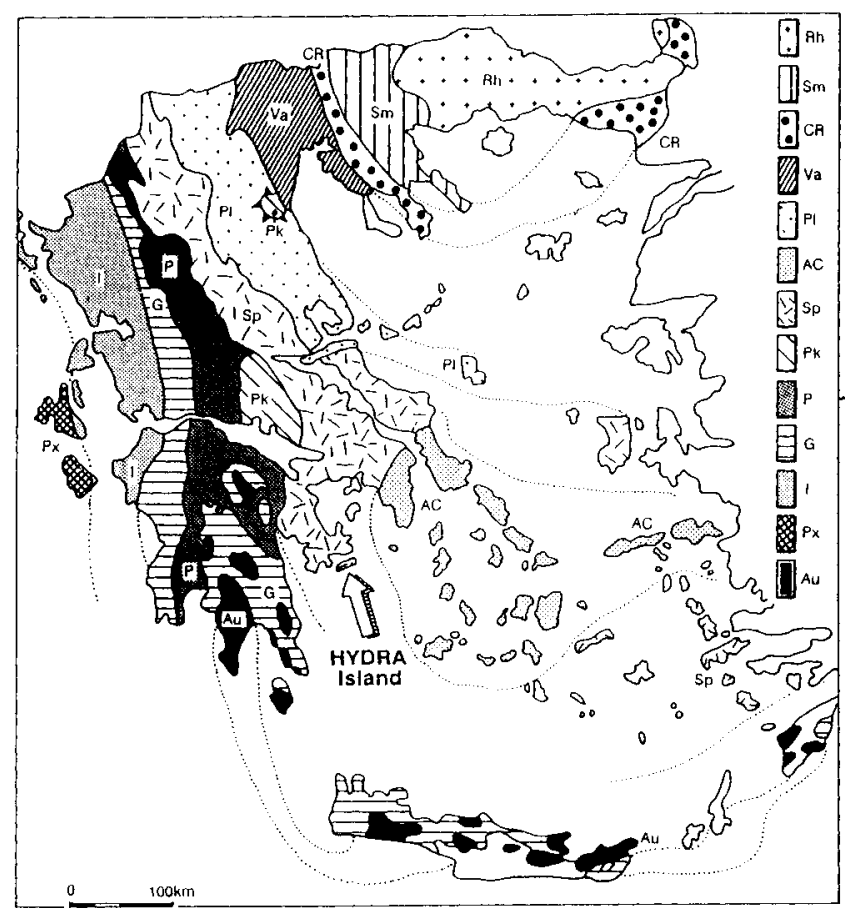

Fig. 1. Structural zones of the Hellenides (modified after Mountrakis et al., 1987). Rh. Rhodope; Sm: Serbomacedonian; CR: Circum Rhodope; Va: Vardar; PI: Pelagonian; AC: Attico-Cycladic; Sp: Subpelagonian; Pk: Parnasos; P: Pindos; G: Gavrovo Tripolis; I: Ionian; Px: Paxos; Au: Plattenkalk-Talea Ori.

lematica). Microfacies 4 has been detected only at $O$. Malies and consists of bindstones made by encrusting problematica organisms (Tubiphytes obscurus, Porostromata and Spongiostromata).

The dark member $(0-200 \mathrm{~m}$ thick) interfingers with the Eros Limestone sensu stricto (Fig. 2) and consists of well-bedded platy beds (centimetres to decimetres thick) of dark limestone with chert. Massive beds of intraformational breccias are present and a later dolomitization is also evident.

The dark member and the Eros Limestone sensu stricto are overlain by the upper lithozone (10-30 $\mathrm{m}$ thick), made up of red matrix-bearing calcareous breccias with bioclastic clasts.
The depositional environment of the Eros Limestone is characteristic of a carbonate platform developed on a marine terrigenous flat (Aghios Nikolaos Formation). Oolitic and bioclastic grainstones and packstones, probably forming sand bars, are widespread. In places (Aghios Marina), these bars seem to have enclosed lower energy areas where mudstones and wackestones were deposited. A hard rim (bindstone) is present in the northeastern part of Hydra (O. Malies) and is apparently localized only at this site. The dark member probably represents not very deep and poorly oxygenated troughs dissecting the carbonate platform. Their areal distribution, in a narrow SW-NE alignment, which together with the presence of abundant intraformational breccias, seems to suggest a tectonic (extensional) origin.

The age of the Eros Limestone ranges from Spathian to the Pelsonian substage of the Anisian (Fig. 2), based on the presence of Spathian bivalves in the lower lithozone, Late Scythian conodonts (Neospathodus homeri (Bender) in sample MR225) in the dark member of the Eros Limestone and Pelsonian conodonts (Gondolella bulgarica (Budurov \& Stefanov), G. bifurcata bifurcata (Budurov \& Stepanov), $G$. bifurcata hanbulogi (Sudar \& Budurov), and Gladigondolella tethydis (Huckriede)) in the upper lithozone [all the condononts listed in this paper and their stratigraphic ranges have been determined by A. Nicora, University of Milan, and are taken from Angiolini et al., 1992]. The foraminiferal assemblages are in agreement with and support this age determination.

\section{SCYTHIAN FORAMINIFERAL ASSEMBLAGE}

This foraminiferal assemblage is recorded mainly in the lower lithozone, in the dark member of the Eros Limestone and also in microfacies 1 of the Eros Limestone s.s: (Fig. 4, sections 1, 2, 4, 5; Table 1). It is characterized by: Glomospira spp., Glomospirella spp., Pilammina praedensa Urosevic, Meandrospira pusilla (Ho), Meandrospira cheni (Ho) and Krikoumbilica pileiformis He. The occurrence of the conodont Neospathodus homeri (Bender) and the Spathian bivalves (Unionites sp. and Eumorphotis sp.) in the dark member and lower lithozone of the Eros Limestone, respectively, confirms the Scythian age of this foraminiferal association.

Of interest is the occurrence of Krikoumbilica pileiformis He in the Scythian stage; this species, up until now, is known

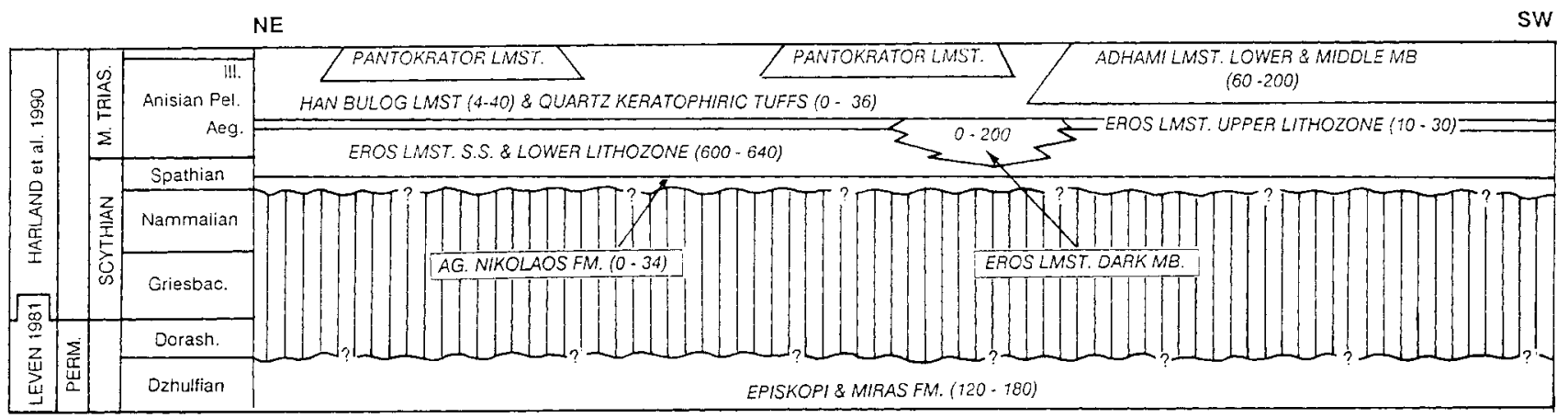

Fig. 2. Stratigraphy of the Triassic succession in Hydra. 


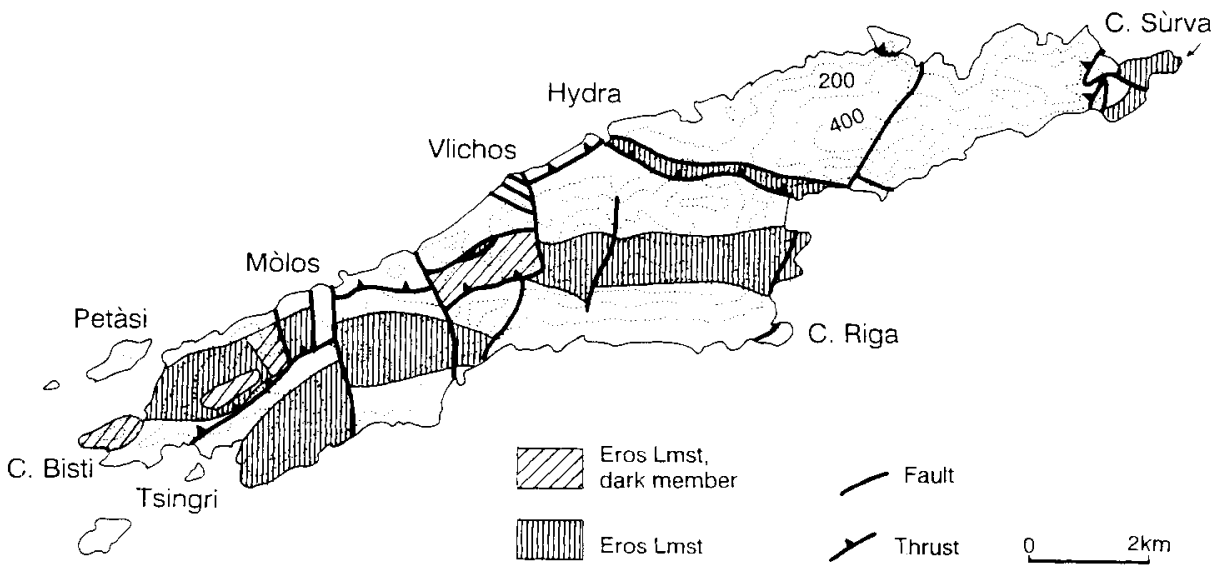

Fig. 3. Geological sketch map showing the distribution of the Eros Limestone (modified after Angiolini et al., 1992).

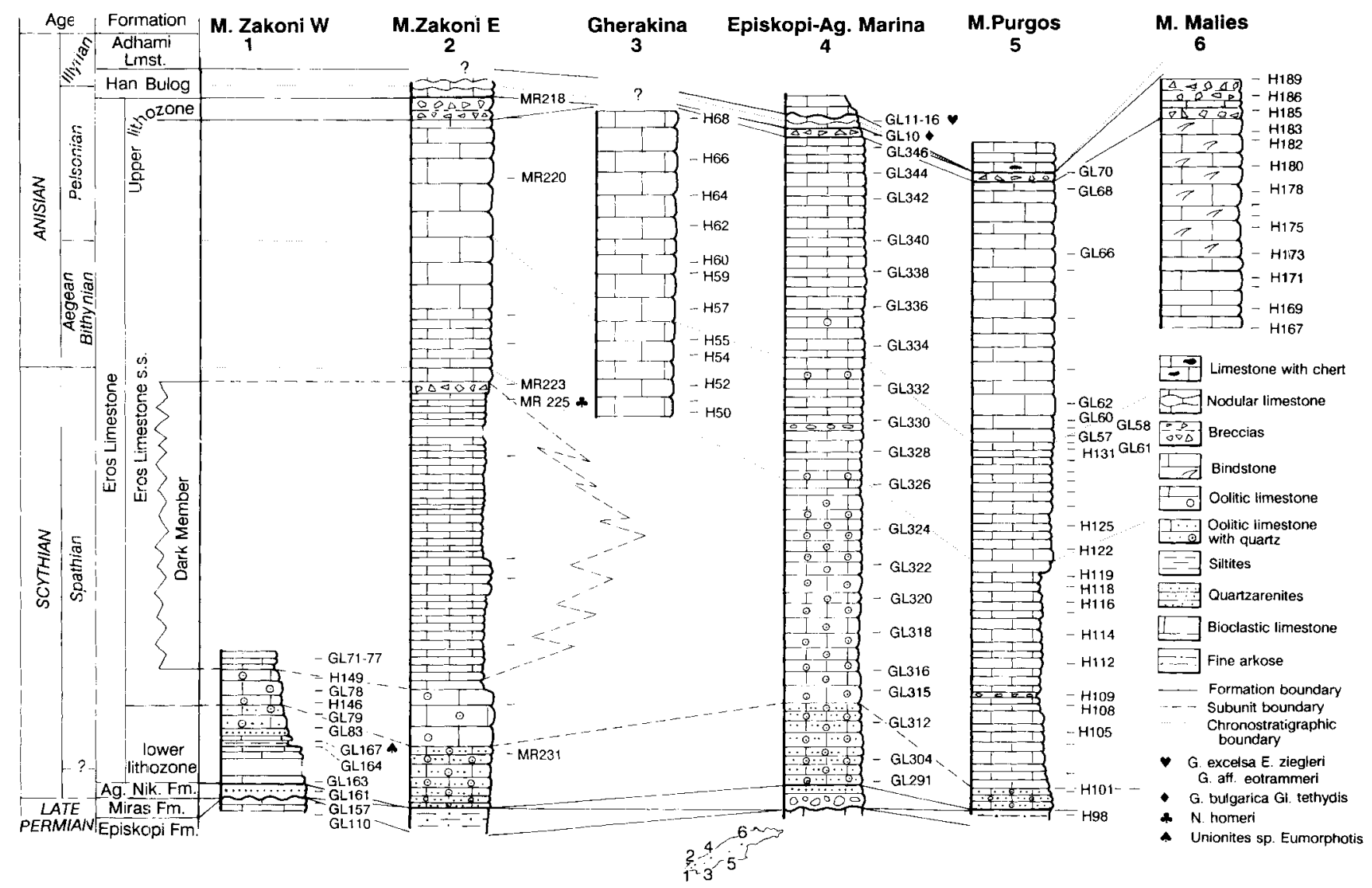

Fig. 4. Stratigraphic sections (left to right: 1-6) measured in the Eros Limestone and their correlation based on foraminiferal and conodont biostratigraphy (for more detailed conodont distribution see Angiolini et al., 1992). To keep the figure more readable, the Eros Limestone s.s. microfacies have not been included. Make reference to Fig. 5, using plotted sample numbers, to locate these microfacies. Section location is as follows: Section 1, southwestern slope of O. Zakoni from $200 \mathrm{~m}$ a.s.l. to the summit; Section 2, southeastern slope of O. Zakoni; Section 3, westward of the village of Gherakina from $240 \mathrm{~m}$ a.s.l. to the southern coast; Section 4, from the ancient village of Episkopi to Ag. Marina chapel; Section 5. from $290 \mathrm{~m}$ a.s.l. on the southern slope to $380 \mathrm{~m}$ a.s.l. on the northern slope of O. Purgos: Section 6, along the new road from $180 \mathrm{~m}$ a.s.I above C. Riga towards the northeast (Ag. Triada). 
Rettori, Angiolini \& Muttoni

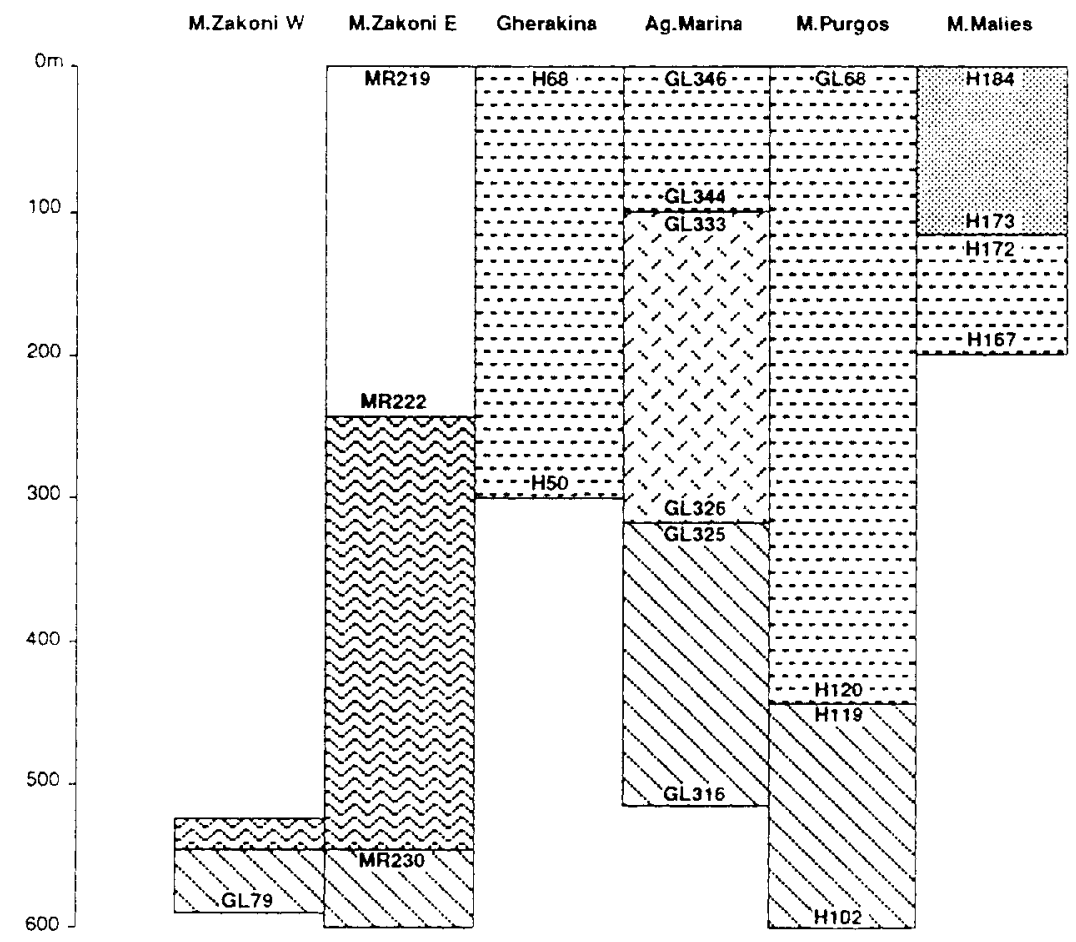

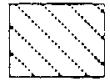

microfacies 1: grainstones, packstones, wackestones with oolites, rare gastropods. bivaives, echinoderms, ostracods, toraminiiers.

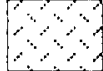

microfacies 2: mudstones, wackestones with oolites, intraclasts, peloids, rare bioclasts.

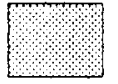

microfacies 4 . packstones with cements and many probiematica (bindstone).

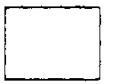

recrystallized limestone

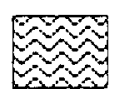

Eros Lmst dark member: mudstones, spicules, toraminifers. [a. microfacjes 3 : packstones, wackestones with $\because \ldots-$ echinoderms, gastropods, stromatolites.

Fig. 5. Distribution and thickness of the microfacies of the Eros Limestone s.s. Numbers refer to samples defining the base and top of each microfacies.

only in the Middle Triassic of southern Guizhou (China). Furthermore, in Hydra, the stratigraphic range of $M$. pusilla (Ho) also extends into the Anisian (see below), whereas $M$. cheni (Ho) appears to be restricted to the Scythian.

\section{ANISIAN FORAMINIFERAL ASSEMBLAGE}

The Anisian foraminiferal assemblage of Hydra is very rich, diverse and well preserved in most samples. It occurs in the Eros Limestone s.s. mainly in microfacies 3 and 4 , more rarely in microfacies 2 (Figs 4-5). These foraminifera belong to the Early and Middle Anisian time interval on the basis of the conodont association (listed above) recorded in the upper lithozone of the Eros Limestone, which directly overlies microfacies 3 and 4 of the Eros Limestone s.s. The typical Anisian foraminiferal assemblage is represented by
(Fig. 4, sections 2, 3, 4, 5, 6; Table 1): Glomospira spp. (Pl. 1, fig. 11), Glomospirella grandis (Salaj), Glomospirella spp., Pilammina densa Pantic, Ammobaculites/Reophax sp., Earlandia amplimuralis (Pantic) Fig. 6.2, Earlandia tintinniformis (Misik) (Fig. 6.3), Endothyra aff. E. salaji Gazdzicki (in Gazdzicki et cl., 1975), Endothyra sp. (Pl. 2, fig. 9, 10), Endoteba sp., Endothyranella wirzi (KoehnZaninetti), Palaeomiliolina judicariensis (Premoli Silva), Meandrospira pusilla (Ho), Meandrospira dinarica Kochansky-Devidé \& Pantic, 'Meandrospira'? deformata Salaj, Meandrospiranella sp., Turriglomina magna (Urosevic), Ophthalmidium spp. (Figs 6.5, 6.6), Spirillina sp. (Pl. 6, fig. 4, 5), Turrispirillina prealpina Zaninetti \& Brönnimann (in Zaninetti et al, 1972a), Triadodiscus or Aulotortus n. sp., ?Lamelliconus sp. (Pl. 6, fig. 9) and 

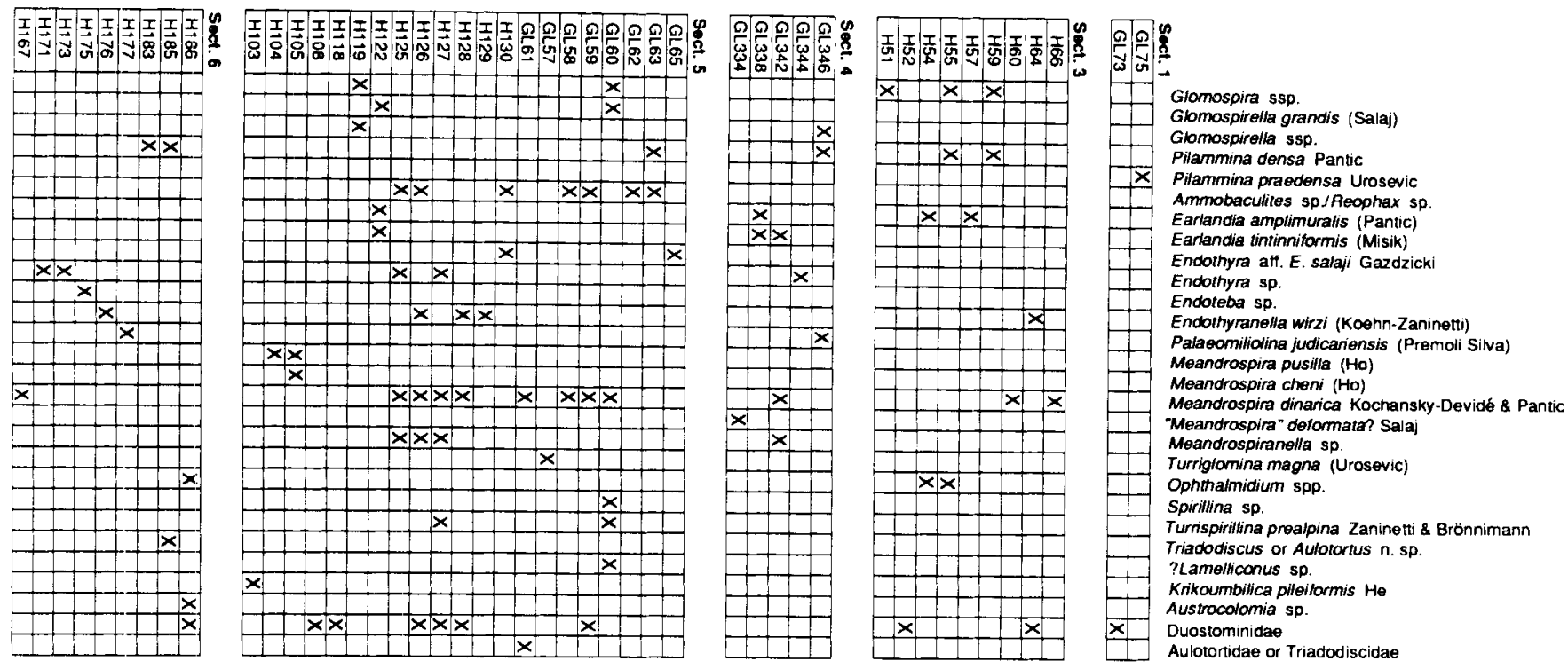

Table 1. Chart of Triassic foraminifera from five out of the six measured sections in the Eros Limestone, Hydra. Section 2 is barren of foraminifera.

Austrocolomia sp. (Fig. 6.5). Duostominidae (Figs 6.1, 6.4), Nodosariidae and a single section of a specimen tentatively assigned to the family Aulotortidae or Triadodiscidae (Pl. 6, fig. 10) were also found. Tubiphytes obscurus Maslov, encrusting, foraminifera (Nubecularia sp.), dasyclad algae, echinoderm fragments, Gemeridella minuta Borza \& Misik and Bacinella irregularis Radoicic are also present.

In the Eros Limestone (upper lithozone), the joint occurrence of Meandrospira pusilla and $M$. dinarica has been detected in sample GL 155 (Tsingri Bay, in front of Tsingry Island, see Fig. 3); the age of this assemblage is Pelsonian on the basis of conodonts. This points to a Scythian-Anisian distribution of $M$. pusilla.

In the overlying Han Bulog Limestone, T. mesotriasica (Koehn-Zaninetti) has been discovered in association with an Illyrian conodont fauna characterized by Gondolella excelsa (Mosher) and Gladigondolella tethydis (sample $\mathrm{H} 4$, Vlichos).

The fauna recorded in the Eros Limestone s.s. of Hydra is very similar to that occurring in the Anisian bioclastic limestone underlying the Han Bulog Limestone of southern (former) Bosnia-Herzegovina, Yugoslavia (Brönnimann et al. 1973a,b). Moreover, it also shows affinities to assemblages of most of the Tethyan Anisian successions recorded by many authors (among others KochanskyDevidé \& Pantic, 1966; Koehn-Zanietti, 1969; Premoli Silva, 1971; Zaninetti et al., 1972a; Efimova, 1974; Gazdzicki et al., 1975; Dager, 1978; Trifonova, 1978a,b; Salaj et al. 1967; Salaj, 1969; Salaj et al., 1983; He, 1984; OraveczScheffer, 1987; Urosevic, 1977, 1981, 1988).

\section{DISCUSSION}

\section{Biostratigraphic considerations}

Angiolini et al. (1992) described the stratigraphy of the Eros Limestone of Hydra, their dating being mainly with the aid of conodont assemblages.
In the present paper we have described the foraminiferal fauna recorded in the same stratigraphic interval, providing further data on the occurrence of some important Early and Middle Triassic foraminifera (Table 2) in the Tethyan realm. Of particular importance are the following:

(A) Pilammina praedensa: the Scythian range reported by Urosevic (1988) is here confirmed on the evidence of the associated conodonts and bivalves.

(B) Pilammina densa: in Hydra, this species has been recorded only in the Pelsonian.

(C) Meandrospira: in the Eros Limestone the distribution of this genus suggests the existence of a lineage ( $M$. cheni-M. dinarica) evolving laterally from $M$. pusilla. The arguments supporting this interpretation are: first, the Scythian portion of the Eros Limestone hosts both $M$. pusilla and $M$. cheni; secondly, during the Early Anisian $M$. dinarica appears, surviving until the Pelsonian, together with rare specimens of $M$. pusilla; and thirdly, $M$. cheni has been found only in the Spathian substage.

(D) Krikoumbilica pileiformis: previously, this species has been known only in the Middle Triassic of China. Therefore, its Scythian occurrence in Hydra indicates that it must have appeared first in the Early Triassic.

(E) Glomospirella grandis: in Hydra, it has been found only in the Anisian (as high as the Pelsonian), in association with Meandrospira dinarica, thus confirming the restriction of this species to the Anisian.

(F) Endoteba: the Upper Permian genus Endoteba is reported in the Triassic (Pelsonian) for the first time. A more detailed analysis of Triassic 'Endothyras' is needed to confirm this record.

(G) Endothyranella wirzi: this species, also known in the Ladinian (Zaninetti, 1976), is here recorded in the Early Anisian, as high as the Pelsonian. We can confirm that elsewhere this species ranges through the Middle Triassic.

(H) Palaeomiliolina judicariensis: appears to be restricted to 

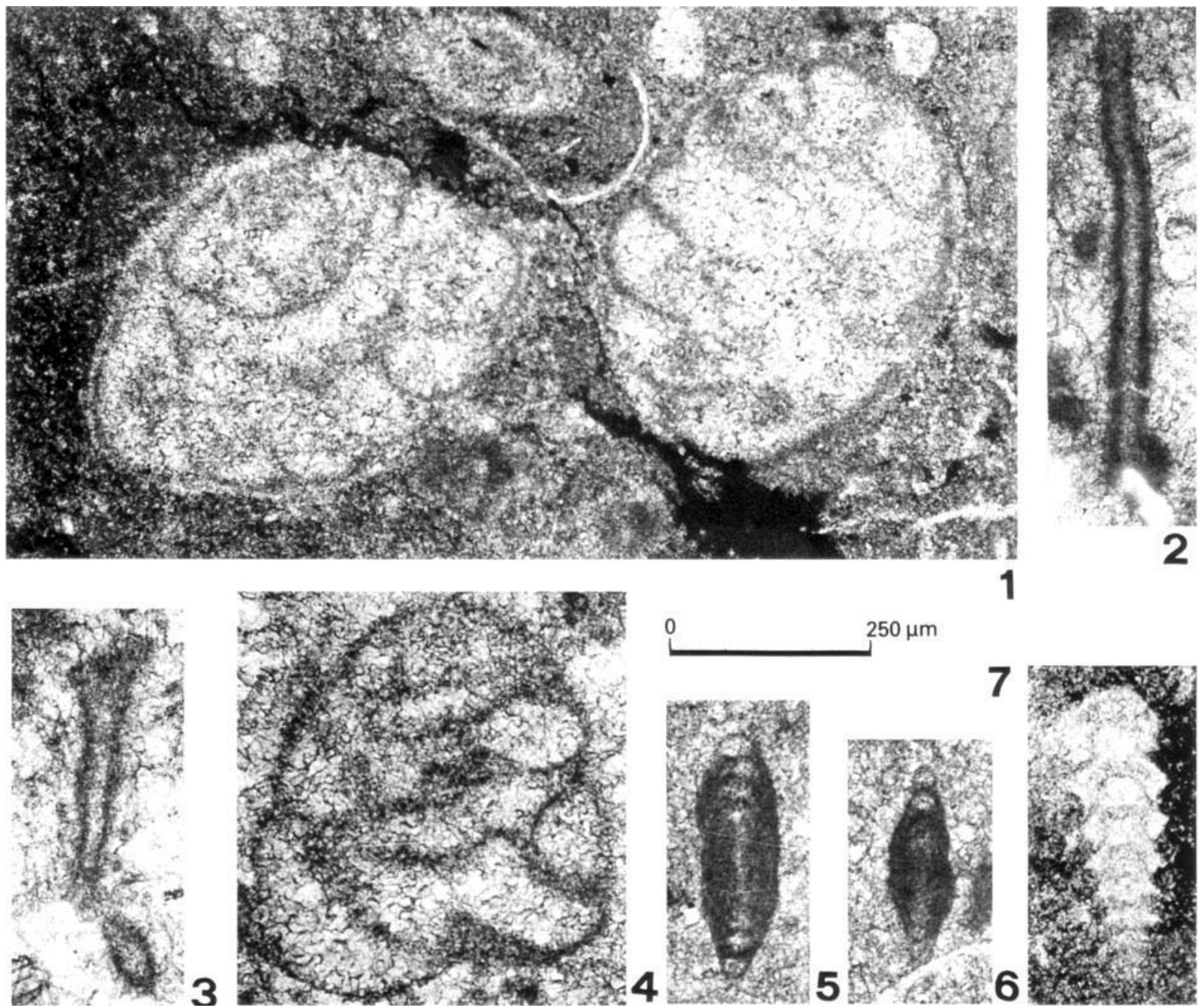

Fig. 6. Thin sections of forminifera. 6.1. Duostominidae: ?Duostomina sp., sample: H186, stratigraphic section 6. 6.2. Earlandia amplimuralis (Pantic), sample: H54, stratigraphic section 3. 6.3. Earlandia tintinniformis (Misik), sample: GL342, stratigraphic section 4. Fig. 6.4. Duostominidae: ?Variostoma sp., sample: H128, stratigraphic section 5. Fig. 6.5, 6.6. Ophthalmidium spp., sample: H55, stratigraphic section 3. Fig. 6.7. Austrocolomia sp., sample: H186, stratigraphic section 6.

the Pelsonian (dating based on associated conodonts); this conclusion is confirmed by other authors (i.e. Premoli Silva, 1971; Trifonova, 1979; Oravecz-Scheffer, 1987).

(I) Turriglomina magna: this species was described by Urosevic in the Carnian-Norian of the Balkans, whereas in Hydra it occurs in the Pelsonian. This confirms the presence of this species in the earliest Middle Triassic, as already suggested by Zaninetti et al. (1990).

(J) Turriglomina mesotriasica: on the co-occurrence of conodonts, the Middle Triassic range of this species is here confirmed.

(K) Turrispirillina prealpina: was recorded for the first time by Zaninetti et al., 1972a in the Late Anisian, whereas in Hydra the species is also present in the Early Anisian only as high as the Pelsonian substage.

(L) Lamelliconus: reported in the Pelsonian substage, apparently for the first time.

(M) A new species of Triadodiscus or Aulotortus has been discovered in the Pelsonian portion of the Eros Limestone s.s. There is an affinity between it and specimens recorded by Brönnimann et al., 1973a,b (as Involutina sinuosa pragsoides) in the Anisian limestone of Bosnia-Herzegovina.

The stratigraphic ranges of the main foraminifera collected in Hydra are shown in Table 2; these results are integrated with data already known from the literature. We do not propose any new foraminiferal zonation but our data has been compared with the zonations proposed by Zaninetti et al. (1972a), Salaj et al. (1988), and Trifonova (1992). In the schemes of Salaj et al. (1988) and Trifonova (1992), a subdivision of the Scythian consisting of a lower, Meandrospira cheni Interval Zone and an overlying, Meandrospira pusilla Interval Zone, was proposed. In Hydra, $M$. cheni appears after the acme of $M$. pusilla in association with rare specimens of $M$. pusilla, disappearing at the end of the Scythian, whereas $M$. pusilla continues into the Anisian in association with $M$. dinarica.

In terms of systematics, it is noteworthy that we refer to $M$. pusilla the smallest forms belonging to the genus Meandrospira of the type-material from China described by Ho (1959), maintaining the name pusilla according to the 


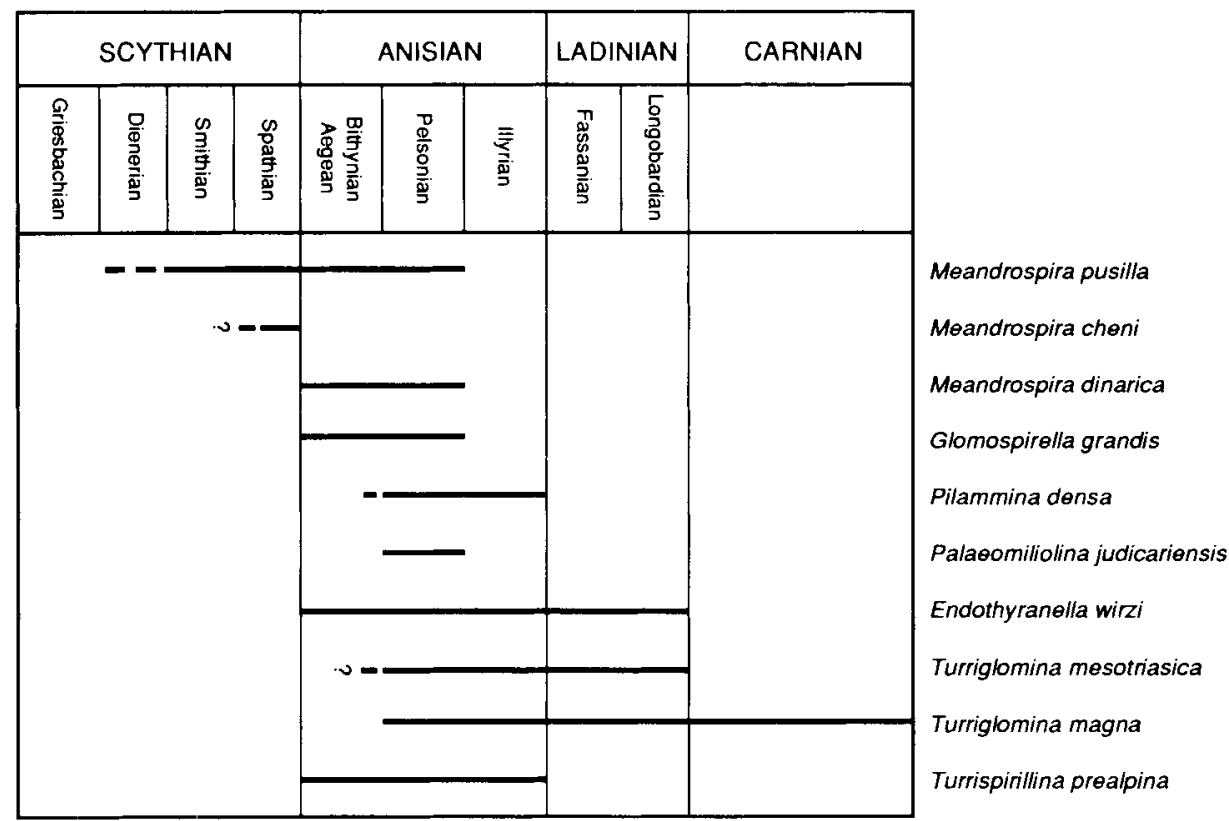

Table 2. Stratigraphic range of some important Triassic foraminifera according to the literature and from new data from the Island of Hydra. See text for discussion.

law of priority (see synonymy). We refer to $M$. cheni those specimens with morphology and dimensions intermediate between $M$. pusilla and $M$. dinarica, as figured by Ho (1959) (see synonymy). During a visit to the Department of Geology and Palaeontology of the Academic Sinica (Nanjing), one of us (R.R.) examined the original collection of Ho Yen and established the true nature of $M$. cheni.

Salaj et al. (1988) established a $M$. dinarica Interval Subzone (Bithynian-Pelsonian) in the lower part of the Pilammina densa Range Zone (Bithynian-Illyrian). Trifonova (1992) basically agrees with this zonation but differs in the detail of her subdivisions of the Pelsonian. The $M$. dinarica Subzone was raised to a full Zone by Zaninetti et al. (1972a).

In Hydra, $M$. dinarica appears at the base of the Anisian and continues to the top of the Pelsonian, whereas $P$. densa appears during the Pelsonian. According to our data, the range of $M$. dinarica is therefore lower compared to previous zonations. Furthermore, we have found $M$. dinarica in association with Aulotortus or Triadodiscus n.sp. (= Involutina sinuosa pragsoides sensu Brönnimann et al., 1973a).

\section{Palaeogeographic considerations}

Palaeogeographically, there is a particular similarity between the foraminiferal fauna of Hydra and that recorded by Brönnirnann et al. (1973a,b) from the Anisian of southern Bosnia-Herzegovina, as well as in other localities of the Dinarides (Kochansky-Devidé \& Pantic, 1966; Urosevic, 1977, 1981, 1988). Lithological and faunal similarities suggest a possible correlation between the Dinarides and the Subpelagonian Zone of the Internal Hellenides (Hydra Island).

Our faunas also show many affinities with those reported from the Middle Triassic of the Southern Alps (Gaetani \& Gorza, 1989), the Carpathians (Gazdzicki, et al., 1975; Trifonova, 1978a,b; Oravecz-Scheffer, 1987), the Kocaeli Peninsula (Turkey) (Dager, 1878), the Caucasus (Efimova, 1974) and from China (He, 1984).

In the M. Facito Formation auct. of the Lagonegro area (Southern Apennines), an Illyrian-Landinian foraminiferal fauna, calibrated with conodonts (Ciarapica et al., 1990; Mietto et al., 1991), has been studied. This foraminiferal assemblage is similar to the Illyrian fauna recorded in Hydra; particularly they share, amongst others, the species Turriglomina magna, T. mesotriasica and Endothyranella wirzi. During the Pelsonian the carbonate platform of Hydra was characterized by the occurrence of Meandrospira dinarica, Pilammina densa, Palaeomiliolina judicariensis, and Triadodiscus/Aulotortus n.sp. This fauna is completely absent in the Lagonegro sequence; in fact, during this period Lagonegro is affected by terrigenous influxes, causing carbonate sedimentation to occur only from Illyrian time.

In conclusion, the two successions of Hydra and Lagonegro show affinities, testifying to a similar evolution of the passive continental margin, even if they were developed at slightly different times. In Hydra, the carbonate platform (Eros Limestone) which had developed from Scythian to Pelsonian time, becoming drowned during the Pelsonian, whereas the carbonate platform of the Lagonegro area is referable to the Illyrian-Longobardian and became drowned at several different times within the Ladinian.

\section{SYSTEMATIC DESCRIPTIONS}

Citations, post-1976, are given in full to show the wide distribution within Tethys of these important foraminifera and as a supplement to the detailed synonymies given by Zaninetti (1976). The reader is referred to Tables 1 and 2 
for the distribution of the species in Hydra. For the position of the samples and for the lithologies quoted in the text below, see also Figs 4,5 .

Order Foraminiferida Eichwald, 1830

Superfamily Ammodiscacea Reuss, 1862

Family Ammodiscidae Reuss, 1862

Subfamily Ammoveretellininae Saidova, 1981

Genus Glomospirella Plummer, 1945

Glomospirella grandis (Salaj, in Salaj, Biely \& Bistricki, 1967)

(Pl. 1, figs 9, 10)

For synonymies before 1976, see Zaninetti (1976: 101).

1977 Glomospirella grandis (Salaj); Pantic-Prodanovic \& Radosevic: 79, pl. 4, figs 3, 4.

1978 Glomospirella grandis (Salaj); Dager: 50, pl. 1, fig. 3. 1983 Pilamminella grandis Salaj; Salaj et al.: 68, pl. 12, figs 1, 2.

1983 Pilamminella semiplana (Kochansky-Devidé \& Pantic); Salaj et al:: 69, pl. 12, fig. 3, 4.

?1989 Glomospirella semiplana (Kochansky-Devidé \& Pantic); Gaetani \& Gorza: 46, pl. 11, figs 7, 8.

1989 Glomospirella grandis (Salaj); Gaetani \& Gorza: 46, pl. 12, fig. 1.

1990 Glomospirella falsofriedli (Salaj, Borza \& Samuel); He \& Wang: 67, pl. 1, figs 12,13 .

1990 Glomospirella grandis (Salaj); He \& Wang: 66, pl. 1, figs $15,16$.

1992 Pilamminella semiplana (Kochansky-Devidé); Trifonova: 21 , pl. 1 , fig. 10 .

Remarks. Among the Triassic glomospirellas it is the largest in size (with a maximum diameter of $1.5 \mathrm{~mm}$ according to Zaninetti, 1976). The species is very distinctive as it is characterized by a wide, streptospirally enrolled initial part and then by a planispiral stage (3-5 whorls).

$G$. grandis has been recorded in the Anisian throughout Tethys, often associated with Pilammina densa and Meandrospira dinarica. The species was named, but not figured, by Ramovs (1972) from the Carnian of Dinarids.

In Hydra, our specimens are associated with $M$. dinarica, ?Lamelliconus sp. and Turrispirillina prealpina and range from Early Anisian to Pelsonian, on the basis of associated conodonts faunas.

Occurrence. O. Purgos, Eros Limestone s.s., section 5, sample H 122, GL 60.

Genus Pilammina Pantic, 1965

Pilammina densa Pantic, 1965

(Pl. 2, figs 1, 2, 3?, 4, 5?)

For synonymies before 1976, see Zaninetti (1976: 89).

1976 Glomospira densa (Pantic); Urosevic \& Dumurdanov:

93, pl. 2, fig. 4.
1977 Glomospira densa (Pantic); Pantic-Prodanovic \& Radosevic: 79 , pl. 4, figs 5, 8 .

1977 Glomospira densa (Pantic); Gazdzicki \& Smit: 326, pl. 3 figs $4-9$.

1977 Glomospira densa (Pantic); Urosevic: pl. 2, figs 6, 7.

1978 Glomospira densa Pantic; Dager: 49, pl. 1, fig. 2.

1983 Pilammina densa Pantic; Salaj et al.: 66, pl. 9, figs 1-4. 1084 Glomospira densa (Pantic); He Yan: 422, pl. 1, figs $1-6,7$ ?

1986 Pilammina densa Pantic; Sudar: 352, pl. 17, figs 1-4.

1988 Glomospira densa (Pantic); Pirdeni: 147, pl. 1, figs 8, 9. 1990 Glomospira (Pantic); He \& Wang; 65, pl. 1, figs 1-10. 1990 Glomospira densa Pantic (sic); Lualdi \& Bianchi: 48, fig. $10(8)$.

1992 Pilammina densa Pantic; Trifonova: 20, pl. 2, figs. 10, 11; pl. 4, fig. 15 .

Remarks. The specimens from Hydra are comparable with Pantic's original material, except for the high number of convolutions in the latter (40-60 in Pantic, 1965).

$P$. densa is known from the Anisian of many Tethyan localities (i.e. Dinarides, Hellenides, W. Carpathians, Giudicarie Alps, Northern Calcareous Alps, Swiss Prealps, Kocaeli Peninsula (Turkey), Qinghai and Guizhou provinces of China). The species is frequently mentioned in association with Meandrospira dinarica and Glomospirella grandis. We have found $P$. densa, together with the same Involutinacea (Triadodiscidae or Aulotortidae) recorded by Brönnimann et al. (1973a,b) and assigned by these authors to Involutina sinuosa pragsoides (Oberhauser), but we have never found $P$. densa either with $M$. dinarica or Glomospirella grandis.

Our specimens occur in the upper part of the stratigraphic sections (5 and 6), attributed to the Pelsonian on the basis of the conodont association $(G$. bulgarica, $G$. b. bifurcata, $G$. b. hanbulogi, Gl. tethydis).

Occurrence. O. Malies, Eros Limestones s.s., section 6, samples GL 183, GL 185; O. Purgos, Eros Limestone s.s., section 5, sample GL 63; Aghios Marina, Eros Limestone s.s., section 4, sample GL 346; Gherakina, Eros Limestone s.s., section 3 , samples H 55 , H 59 .

Pilammina praedensa Urosevic, 1988 (Pl. 1, figs 3, 4)

1988 Pilammina praedensa Urosevic: 377 , pl. 1, figs 1-6.

Remarks. The species can be distinguished from $P$. densa Pantic in being smaller in size, in having a smaller number of convolutions and less tightly coiled initial whorls.

Pilammina praedensa is known from the Scythian of the Inner Belt of eastern Serbia. The age of $P$. praedensa is confirmed in Hydra by the presence of Spathian bivalves (Unionites sp. and Eumorphotis sp.) and Scythian conodonts (N. homeri).

He \& Cai (1991) determined two specimens recorded in

\section{Explanation of Plate 1}

Fig. 1. Meandrospira pusilla (Ho), sample: H105, stratigraphic section 5. Fig. 2. Meandrospira cheni (Ho), sample: H105, stratigraphic section 5. Figs 3,4. Pilammina praedensa Urosevic, sample: GL75, stratigraphic section 1. Fig. 5. Krikoumbilica pileiformis He, sample: H103, stratigraphic section 5. Figs 6, 7, 8. Undetermined foraminifera, sample: GL76, stratigraphic section 1. Figs 9, 10. Glomospirella grandis Salaj, samples: fig. 9, GL60, stratigraphic section 5; fig. 10, H122, stratigraphic section 5. Fig. 11. Glomospira sp., sample: H51, stratigraphic section 3. 

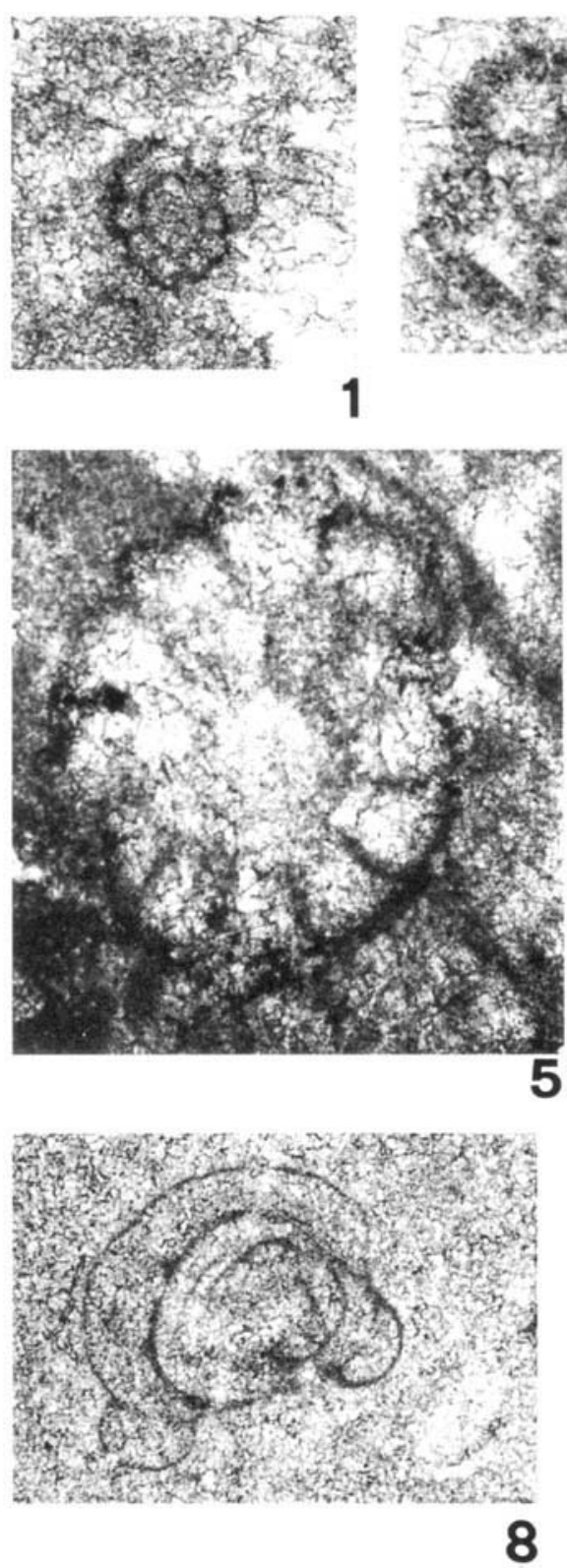
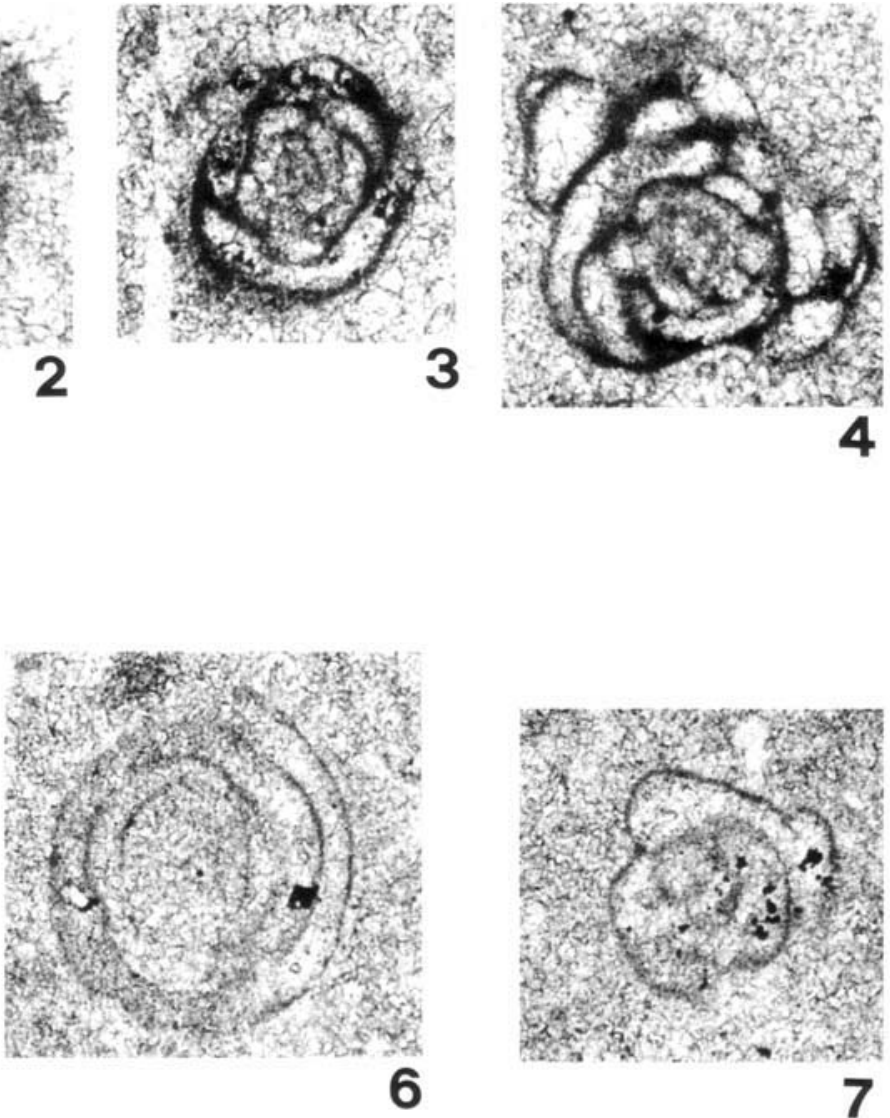

6
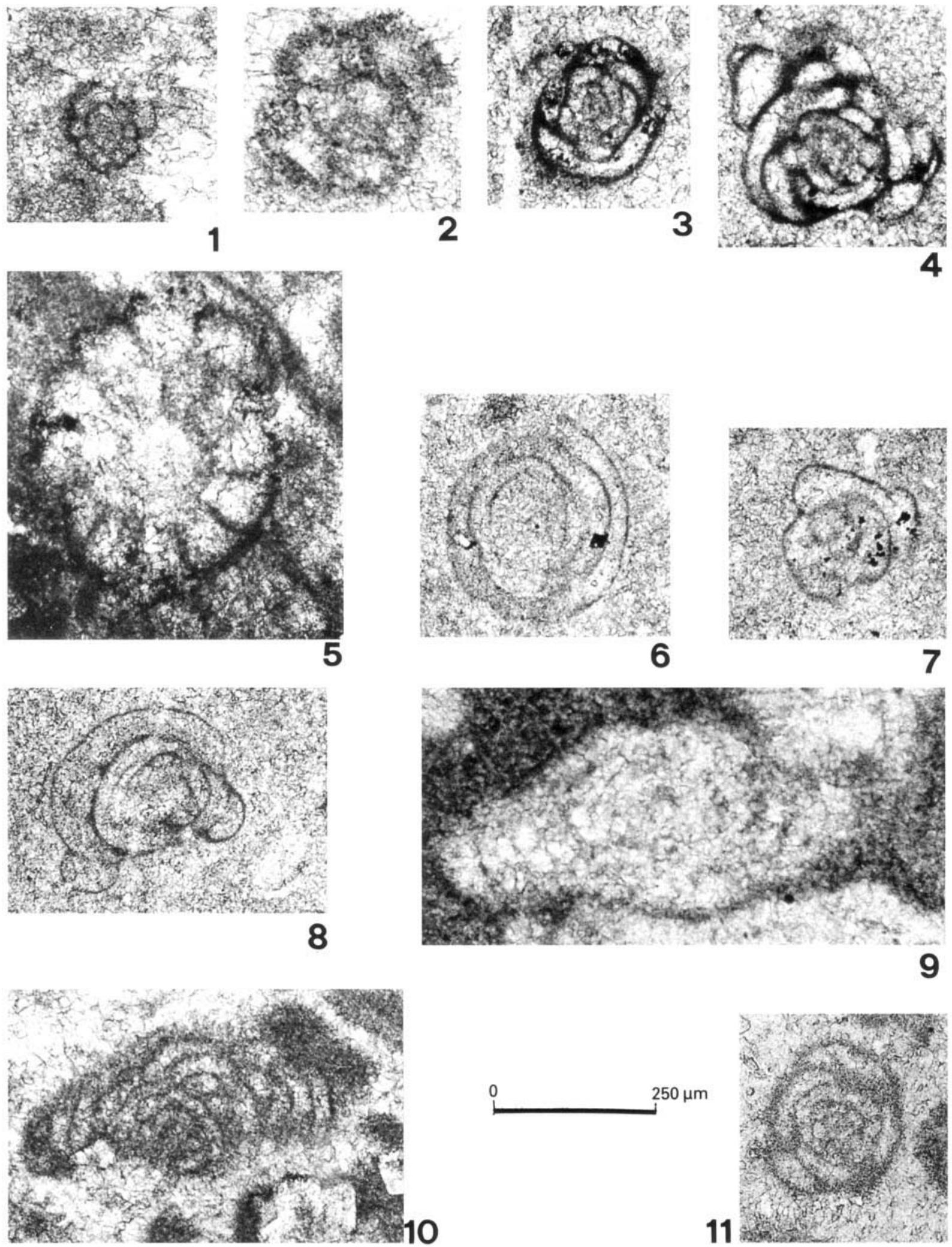

$250 \mu \mathrm{m}$

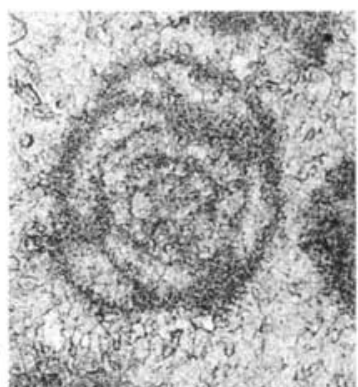


the Middle Triassic Guohua Formation (Guangxi, China) as Glomospira sygmoidalis (Rauser) (pl. 1, figs 3, 4). In our opinion these specimens are very similar to $P$. praedensa and possibly synonymous.

Occurrence. O. Zakoni W, Eros Limestone, dark member, section 1, sample GL75.

Superfamily Endothyracea Brady, 1884 Family Endothyridae Brady, 1884

Subfamily Endothyranospinae Reytlinger, 1958 Genus Endothyra Phillips, 1846,

Endothyra aff. E. salaji Gazdzicki in Gazdzicki, Trammer \& Zawidzka, 1975

(P1. 2, figs 6-8)

aff. 1975 Endothyra salaji Gazdzicki in Gazdzicki, Trammer \& Zawidzka: 289, pl. 5, figs 1-6.

1977 Endothyra malayensis Gazdzicki \& Smit: 324, pl. 8 figs $1-3$.

1983 Endothyra salaji Gazdzicki; Salaj et al.: 90, pl. 38, figs 3,5 .

1984 Endothyra salaji Gazdzicki; He: 426, pl. 3, fig. 10.

Remarks. Our specimens are very similar to the type-material figures in Gazdzicki et al., 1975, but they show larger dimension. The shape and arrangement of the chambers in the last whorls, together with their tendency to uncoil, suggests an affinity with $E$. salaji.

In our opinion, the species E. malayensis Gazdzicki \& Smit, from the (probably Ladinian) Kodiang Limestone (Kedah, North West Malaysia) must be synonymized with E. salaji as it is not possible to recognize significant morphological, dimensional and stratigraphical differences to justify a separate species.

As already pointed out by Koehn-Zaninetti (1969), the presence of tectum and diaphanotheca in the wall of Triassic endothyras is never clear; this is related to an evolutionary simplification of the wall or to diagnetic processes. Vachard \& Razgallah (1988) suggested that most of the Triassic endothyras and endothyranellas are directly linked with their new genus Endoteba, described from the Permian of Jebel Tebaga, Tunisia.

Endothyra salaji was recorded by Gazdzicki et al. (1975) in the Fassanian Muschelkalk of Poland; Oravecz-Scheffer (1987) found, but did not figure the species in the Anisian Falsoör Limestone of Hungary; E. salaji also occurs in the Pelsonian-Illyrian of the West Carpathians (Salaj et al., 1983) and possibly also in the Carnian-Norian of the same region (Salaj et al., 1983); it was also recorded in the Middle Triassic of Guizhou (China) (He, 1984). In Hydra, $E$. aff. $E$. salaji is Early Anisian to Pelsonian in age.

Occurrence. O. Purgos, Eros Limestone s.s., section 5, samples H 130, GL 65.

\section{Genus Endoteba Vachard \& Razgallah, 1988 Endoteba sp.}

(PI. 2, fig. 11)

Remarks. Only one specimen, an equatorial cross-section, corresponds to the morphology of the genus Endoteba as described by Vachard \& Razgallah, 1988 (type species Endoteba controversa, found in the Permian of Jebel Tebaga, Tunisia).

Previously, Endoteba was known only from the Permian, but here it is recorded in the Triassic. However, Vachard \& Razgallah suggest that many Triassic endothyras are morphologically very close to Endoteba and propose a phylogenetic trend between the two genera.

In the Hydra section the genus Endoteba occurs in the Pelsonian.

Occurrence. O. Malies, Eros Limestone s.s., section 6, sample H 175.

Genus Endothyranella Galloway \& Harlton, 1930 Endothyranella wirzi (Koehn-Zaninetti, 1968)

(Pl. 2, fig. 12; Pl. 3, figs 1, 2, 3?, 6; Pl. 4, fig. 5b)

For synonymies before 1976, see Zaninetti (1976: 129)

1977 Endothyranella wirzi (Koehn-Zaninetti); Gazdzicki \& Smit: 323, pl. 7 fig. 10.

1978 Endothyranella wirzi (Koehn-Zaninetti); Dager: 54, pl. 1, fig. 19.

1979? Endothyranella wirzi (Koehn-Zaninetti); He Yan: 1168, pl. 73, fig. 2.

1983 Endothyranella wirtzi (sic) (Koehn-Zaninetti); Salaj et al.: 93, pl. 45, figs 2, 3; pl. 61, figs 1-4.

1983? Endothyranella aff. wirtzi (sic) (Koehn-Zaninetti); Salaj et al: pl. 48, fig. 1.

1986 Endothyranella wirzi (Koehn-Zaninetti); Sudar: 209, pl. 18 , fig. 4 .

1987 Endothyranella wirzi (Koehn-Zaninetti); OraveczScheffer: 95, pl. XX, figs 1-2, 4, 7-9.

1987 Endothyranella cf. wirzi (Koehn-Zaninetti); OraveczScheffer: pl. 20, figs 3, 5 .

1987 Endothyranella? sp.; Oravecz-Scheffer: pl. 20, fig. 6. 1988 Endothyranella wirzi (Koehn-Zaninetti); Pirdeni: 147, pl. 1, fig. 10 .

1988 Endothyranella sp.; Pirdeni: pl. 1, fig. 11.

1989 Endothyranella wirzi (Koehn-Zaninetti); Gaetani \& Gorza: 44, pl. 12, fig. 2.

1989 Ammobaculites radstattensis (sic) Kristan-Tollmann; Gaetani \& Gorza: pl. 12, fig. 3. [Note the mistake in the explanation of the plate: the caption of fig. 4 must be referred to fig. 3 and vice versa].

1990 Endothyranella wirzi (Koehn-Zaninetti); Ciarapica et al.: 154, Fig. 5E.

1991 Ammobaculites radstadtensis Kristan-Tollmann; He \& Cai: pl. 1, figs 20-22.

\section{Explanation of Plate 2}

Figs 1, 2, 3?, 4, 5? Pilammina densa Pantic, samples: fig. 1, H183, stratigraphic section 6; fig. 2, H59, stratigraphic section 5; fig. 3, H55, stratigraphic section 3; figs 4, H185, stratigraphic section 6; fig. 5, GL346, stratigraphic section 4. Figs 6-8. Endothyra aff. E. salaji Gazdzicki, samples: fig. 6, H130, stratigraphic section 5; fig. 7, H130, stratigraphic section 5; 8, GL65, stratigraphic section 5. Figs 9, 10. Endothyra sp., samples: fig. 9, H171, stratigraphic section 6; fig. 10, H173, Stratigraphic section 6. Fig. 11. Endoteba sp., sample: H175, stratigraphic section 6. Fig. 12. Endothyranella wirzi Koehn-Zaninetti, sample: H64, stratigraphic section 3. 


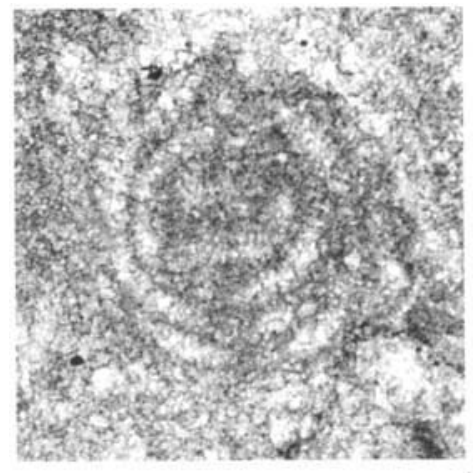

\section{1}
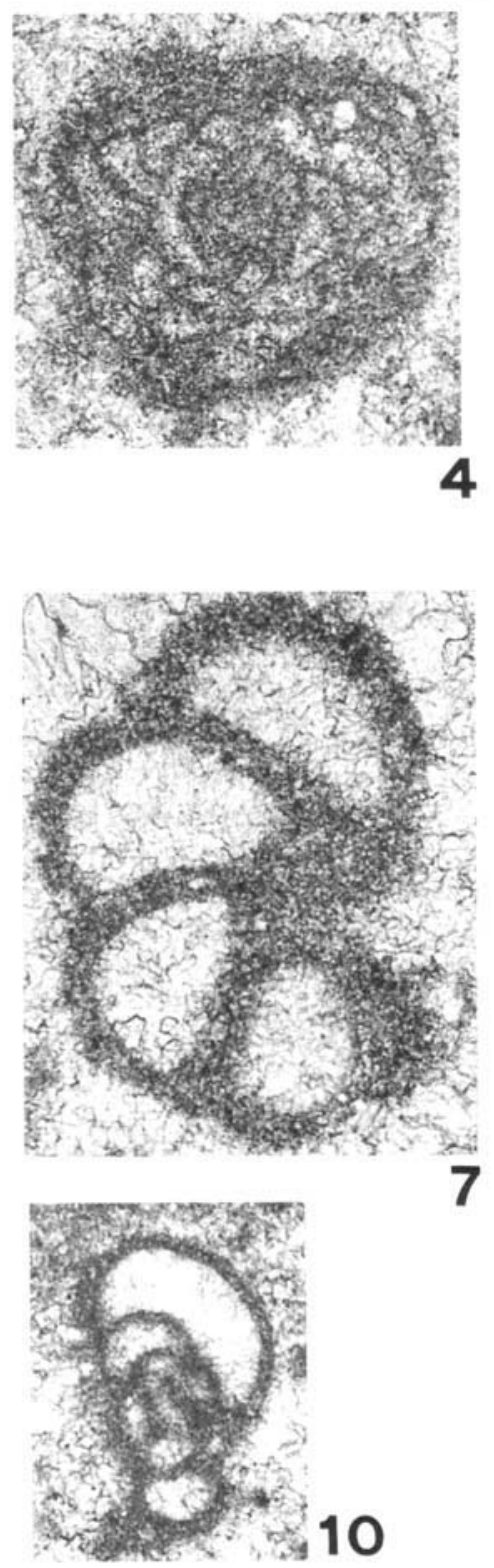

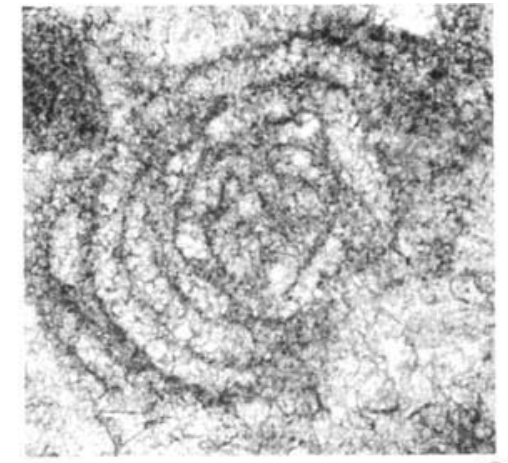

2
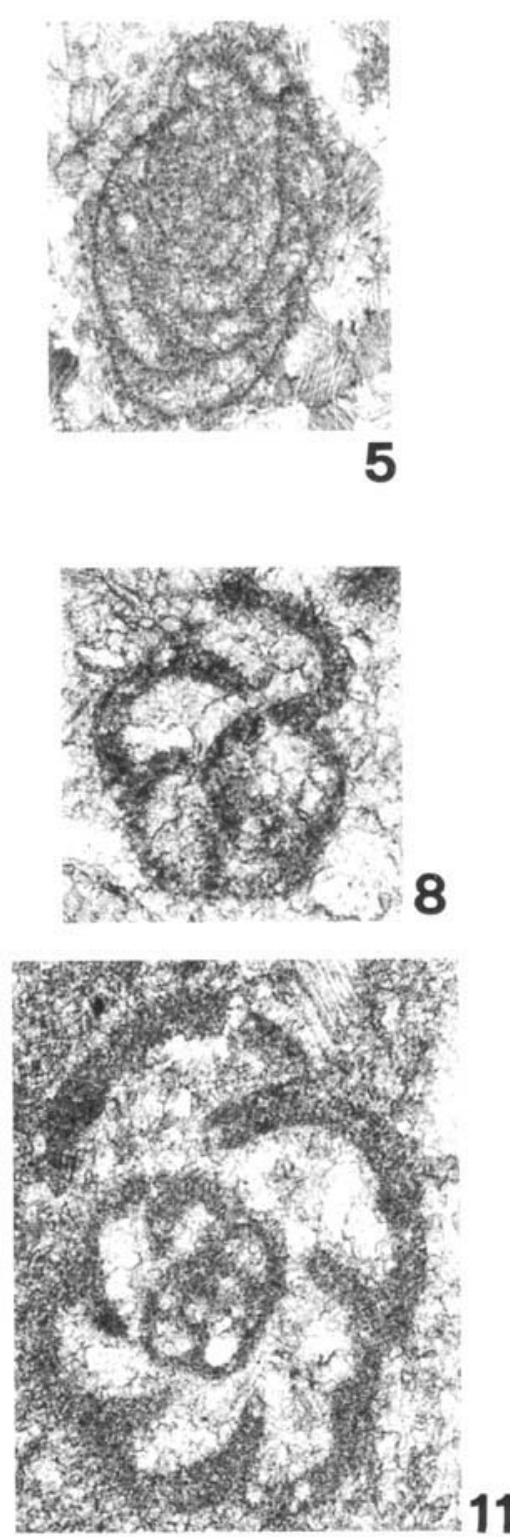
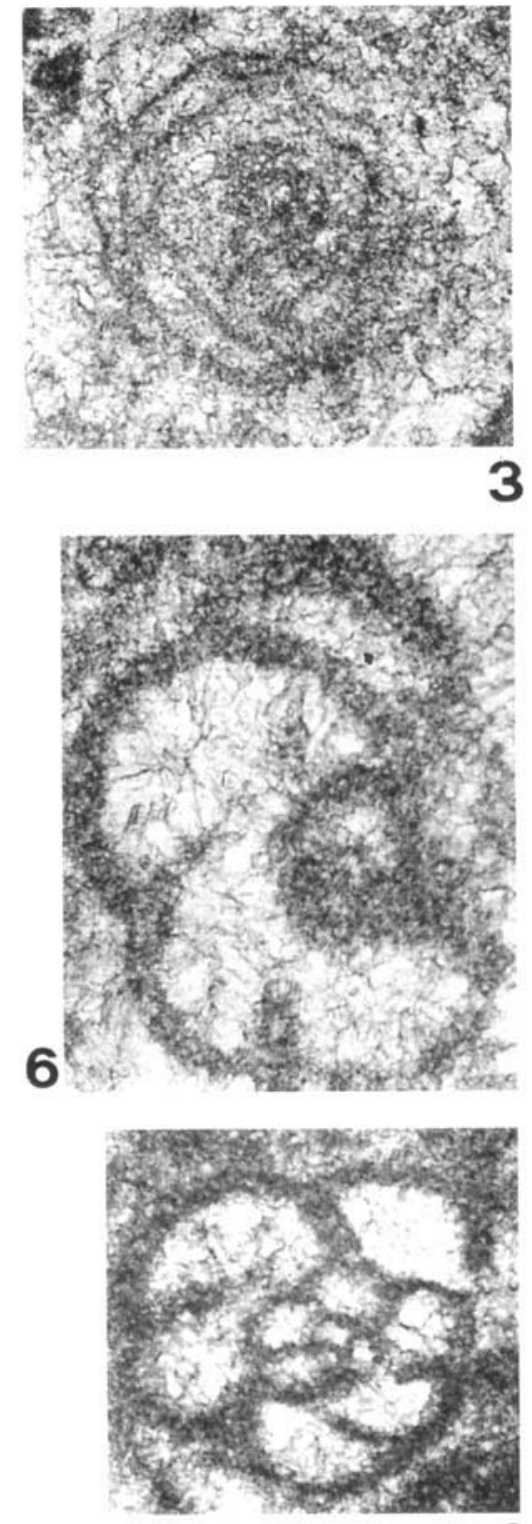

9

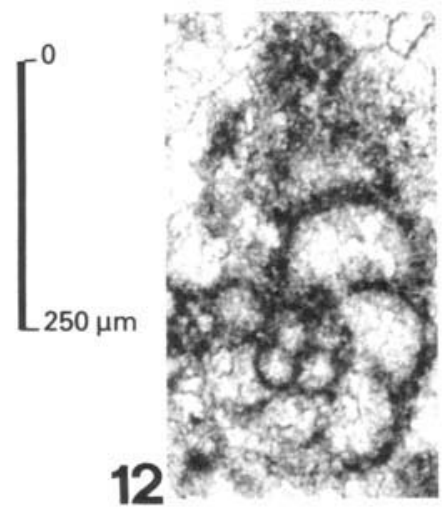


Remarks. All the specimens assigned to $E$. wirzi have characteristics comparable with those mentioned in the original description by Koehn-Zaninetti (1969), although it was not always possible to observe the coiled stage. The globular embracing chambers, the terminal aperture produced on a neck in the uniserial part and the thin microgranular or finely agglutinating wall are diagnostic characteristics of the species.

The specimen figures in our Pl. 2, fig. 12 and others from the literature show a change of coiling plane in the spiral part, this character confirming the attribution of the species to Endothyranella Galloway \& Harlton, rather than to Ammobaculites Cushman, as originally described.

Endothyranella wirzi is known in the Tethyan Middle Triassic, occurring in the Anisian (Koehn-Zaninetti, 1969) and in the Ladinian (Zaninetti, 1976). In Hydra we have recorded the species in the Early Anisian (as high as the Pelsonian).

Occurrence. Gherakina, Eros Limestone s.s., section 3, sample H 64; O. Purgos, Eros Limestone s.s., section 5, samples H 126, H 128, H 129; O. Malies, Eros Limestone s.s., section 6, sample H 176.

\section{Superfamily Cornuspiracea Schultze, 1854 \\ Family Meandrospiridae Saidova, 1981 \\ Subfamily Meandrospirinae Saidova, 1981 \\ Genus Meandrospira Loeblich \& Tappan, 1946 \\ Meandrospira pusilla (Ho, 1959)}

(Pl. 1, fig. 1; Pl. 4, fig. 14)

1959 Trochamminoides pusillus Ho: 416, pl. 7, figs. 18-29; pl. 8, figs. $1-5$.

1959 Trochamminoides flosculiformis Ho: 416, pl. 8, figs. $6-10$.

1959 Trochamminoides insolitus Ho: 416, pl. 8, figs. 11?, 12?, $13-15$.

1959 Trochamminoides cheni Ho: 416 (in part), pl. 8, figs 18, 19 not figs 16,17

1964 Citaella iulia Premoli Silva: 661, pl. 48, figs 1-20; pl. 49 , figs $1-20$; pl. 50, figs $1-7$; pl. 51 , fig. 5 .

For other synonymies before 1976, see Zaninetti (1976: 135). 1976 Meandrospira pusilla (Ho); Zaninetti: 135, pl. 1, figs 5-7, 9-11, not fig. 8 .

1976 Meandrospira forma pusilla Farabegoli et al.: 679, figs.6a, b, f.

1976 Meandrospira forma insolita or pusilla Farabegoli et al.: fig. $6 \mathrm{e}$.

1976 Meandrospira julia (Premoli Silva); Urosevic \& Dumurdanov: 93, pl. 1, fig. 2.

1976 Meandrospira pusilla (Ho); Urosevic \& Dumurdanov: 93, pl. 1, fig, 6.

1977 Meandrospira iulia (Premoli Silva); Pantic-Prodanovic \& Radosevic: 76, pl. 2, figs 6-7.

1977 Meandrospira pusilla (Ho); Trifonova: 32, pl. 2, figs 1, 2 ; pl. 3, fig. 3 .
1977 Meandrospira pusilla (Ho); Gazdzicki \& Smit: 326, pl. 4 , figs $8-10$.

1978 Meandrospira pusilla (Ho); Dager: 55, pl. 2, figs 7, 8. 1983 Meandrospira pusilla (Ho); Salaj et al.: 101, pl. 55, figs $1-15$.

?1983 Meandrospira insolita (Ho); Salaj et al.: 100, pl. 55, figs 16 ?, 17-19a, $19 \mathrm{~b}$.

1983 Meandrospira cheni (Ho); Salaj et al.: 99, pl. 56, figs 6 , $8,10,11,12,14,18$.

1987 Meandrospira pusilla (Ho); Oravecz-Scheffer: 113, pl. 8 , fig. 15 ; pl. 9 , figs $1,2,4$; pl. 11, figs $1,4,5$.

1988 Meandrospira pusilla (Ho); Pirdeni: 146, pl. 1, figs 1-4. 1988 Meandrospira pusilla (Ho); He: 89, pl. 2, figs 10, 12.

1988 Meandrospira immatura $\mathrm{He:}$ 92, pl. 2, figs 13, 14.

1988 Meandrospira insolita (Ho); He: 89, pl. 2, figs 15-18.

1988 Meandrospira pusilla (Ho): Trifonova \& Catalov: 80, pl. 1, fig. 15 .

1990 Meandrospira pusilla (Ho): Lualdi \& Bianchi: 46, Fig. $10(2 \mathrm{a})$.

1990 Meandrospira pusilla (Ho); Baroz et al.: 28, pl. 4, figs $1-6,9,11,12$.

Remarks. Although very rare in our samples from Hydra, our few specimens are morphologically referable to some of the type specimens illustrated by Ho (1959) from the Lower Triassic Chialingkiang Limestone (He, 1979, 1988) of South Szechuan (China) (see also above). M. pusilla is very common in the lower Triassic of all parts of Tethys. It is associated with $M$. cheni in sample H104, Scythian (probably Spathian) in age, and with $M$. dinarica in the sample GL 155 (Pelsonian in age on the basis of conodonts). The presence of rare specimens of $M$. pusilla in the Anisian has already been established by several authors (i.e. Salaj et al., 1967; Bechstädt \& Bradner, 1970; Brönnimann et al., 1973a,b; Farabegoli et al., 1976). In Hydra the coexistence of $M$. pusilla and $M$. dinarica in sediments containing Pelsonian conodonts confirms that even if the acme of $M$. pusilla does occur during the Early Triassic, in favourable palaeoecological conditions (Zaninetti, 1976; Farabegoli et al., 1976; Oravecz-Scheffer, 1987) this species continues into the Anisian.

Occurrence. O. Purgos, Eros Limestone s.s., section 5, sample H 104, H 105; Tsingri Bay, Eros Limestone, upper lithozone, sample GL 155.

\section{Meandrospira cheni (Ho), 1959}

(Pl. 1, fig. 2)

1959 Trochamminoides cheni Ho: 416 (in part), pl. 8, figs 16, 17, not figs 18, 19.

1976 Meandrospira pusilla (Ho); Zaninetti: 135, pl. 1, fig. 8. 1976 Meandrospira forma gigantea Farabegoli et al.: 679, fig. $6 \mathrm{~d}, \mathrm{~g}, \mathrm{~h}$.

1983 Meandrospira pusilla (Ho); Salaj et al:: 101, pl. 56, figs $1-5,7 ?, 9,13 ?, 15 ?, 16 ?, 17 ?, 19$.

\section{Explanation of Plate 3}

Figs 1, 2, 3?, 6. Endothyranella wirzi Kochn-Zaninetti, samples: fig. 1, H126, stratigraphic section 5; fig. 2, H176, stratigraphic section 6; fig. 3, H129, stratigraphic section 5; fig. 6, H64, stratigraphic section 3. Figs 4, 7, 8. Ammobaculites sp./Reophax sp., samples: fig. 4, H126, stratigraphic section $5 ; 7, \mathrm{H} 130$, stratigraphic section $5 ;$ fig. 8, GL62, stratigraphic section 5 . (The vertical scale bar refers to figs 7,8 ). Figs 5,9 . Palaeomiliolina judicariensis (Premoli Silva), samples: figs 10, 11, H125, stratigraphic section 5; fig. 12, H126, stratigraphic section 5. 

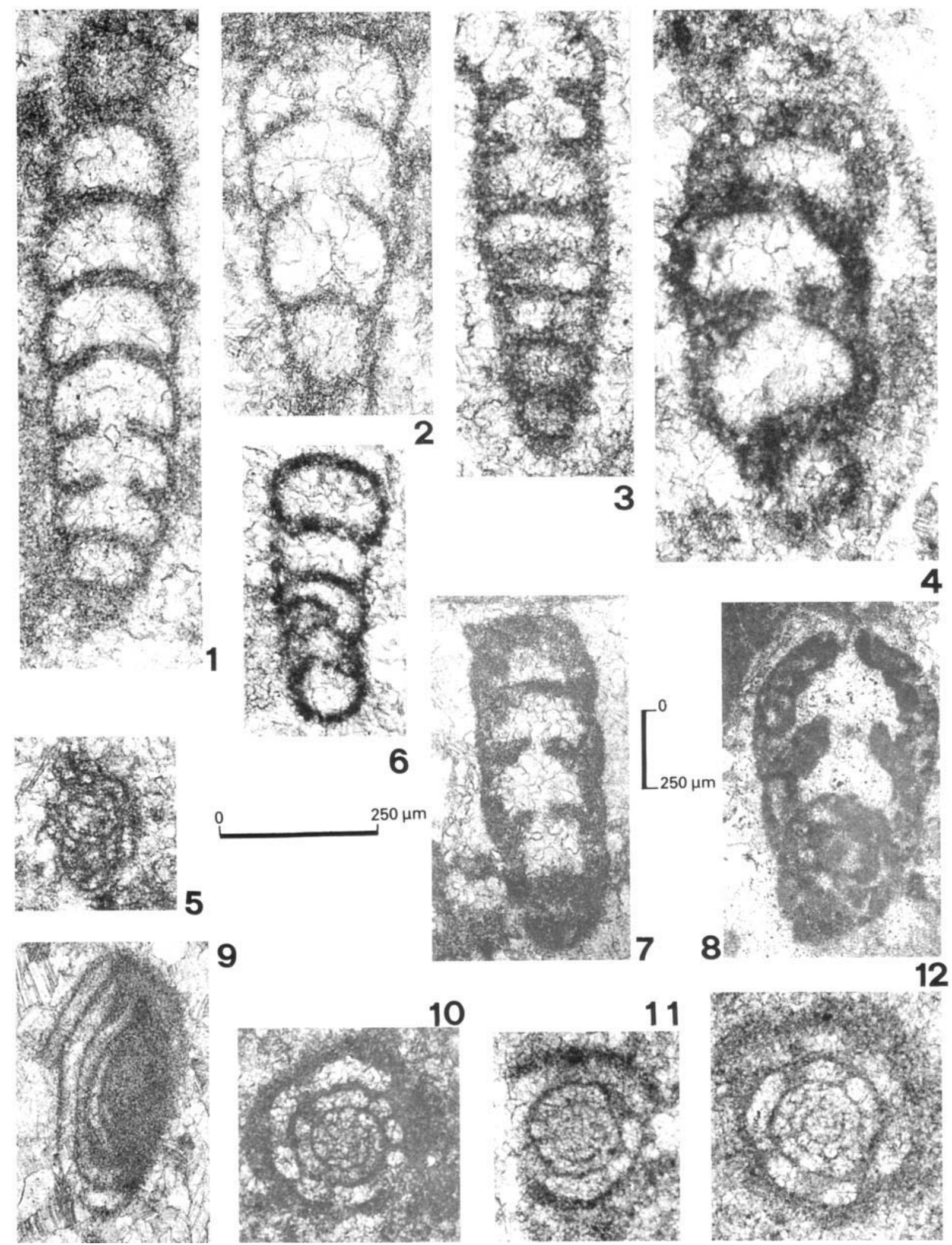

9
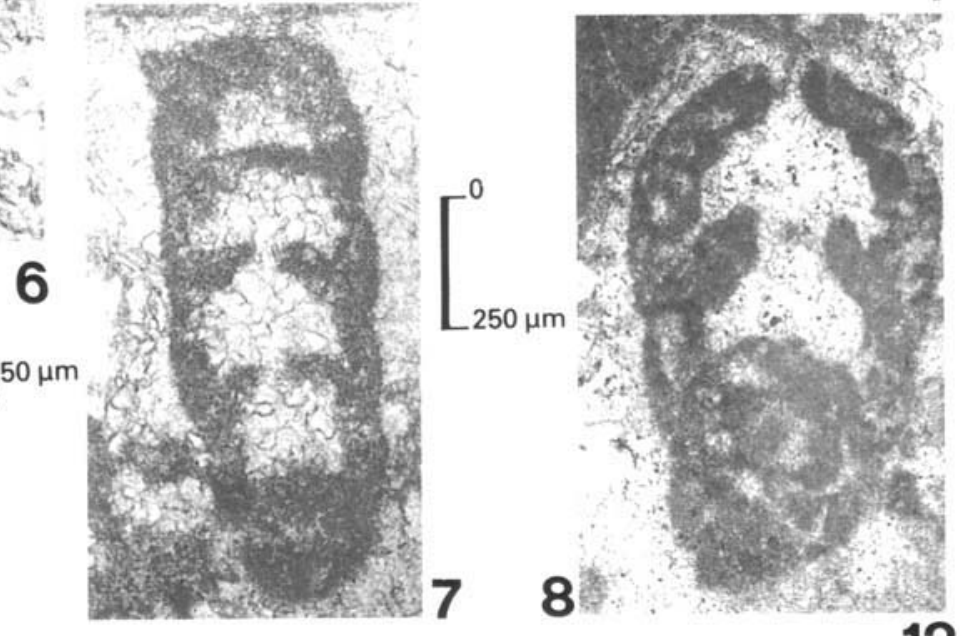

12
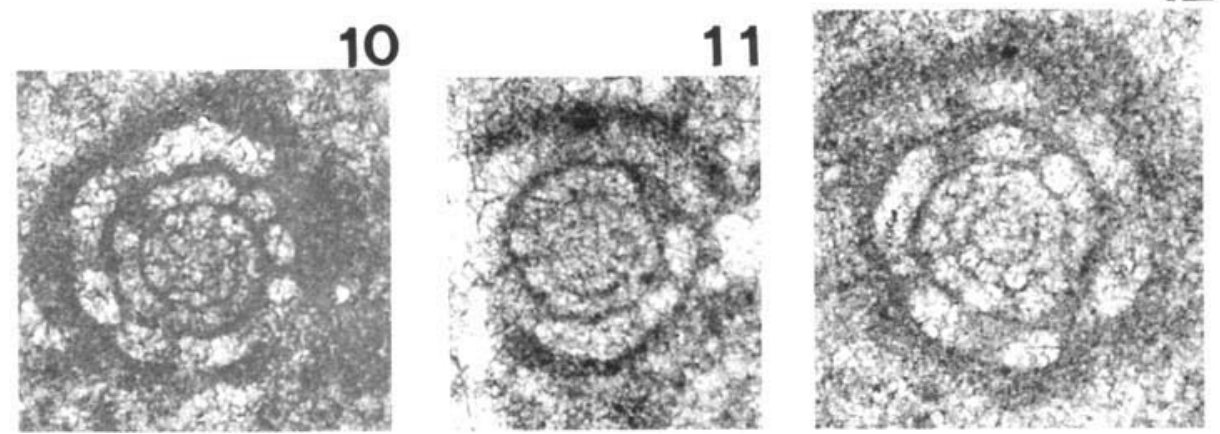
1990 Meandrospira cheni (Ho): Baroz et al: 28 , pl. 4, figs $13-18$.

Remarks. In association with rare specimens of $M$. pusilla in the Scythian of Hydra, we have recorded a few specimens distinguishable from $M$. pusilla on the basis of a reduced number of zigzag bends, together with a smaller size of test and deuteroloculus. Morphologically these specimens are comparable with part of the type-material of Meandrospira cheni (=Trochamminoides cheni Ho, 1959) from China. This species has long been considered a synonym of $M$. pusilla. Recently, Baroz et al. (1990) asserted the validity of $M$. cheni, recorded together with M. pulsilla, in the Lower Triassic of the Oreokastro mountain belt (Greece) and we agree with them in considering $M$. cheni a transitional form between $M$. pusilla and $M$. dinarica. A phylogenetic lineage within this group had already been commented upon by Farabegoli et al. (1976) and by Oravecz-Scheffer (1987). These authors proposed, however, a link through the informal taxon 'Meandrospira forma gigantea' of Farabegoli et al. (1976), recorded in association with both $M$. pusilla and $M$. dinarica. As already noted by Baroz et al. (1990), Farabegoli et al.'s specimens of ' $M$. forma gigantea', found in association with $M$. pusilla, show affinities with $M$. cheni, whereas those associated with $M$. dinarica fall within the intraspecific variation of $M$. dinarica. Specimens of ' $M$. gigantea' figured also by Oravecz-Scheffer (1987) (pl. 13, figs 1-4) seem to belong to dinarica.

In conclusion, we can confirm that in Hydra $M$. cheni occurs together with rare specimens of $M$. pusilla at the base of the Eros Limestone s.s., in the Scythian (probably Spathian), and it is never found above this level. In contrast, $M$. pusilla is present also in the later, Pelsonian portion of Eros Limestone (upper lithozone) together with $M$. dinarica. Occurrence. O. Purgos, Eros Limestone s.s., section 5, sample H 105.

Meandrospira dinarica Kochansky-Devidé \& Pantic, 1966

(Pl. 3, figs 10-12; Pl. 4, figs 1-13, 15; Pl. 5, figs 1-2)

1966 Meandrospira dinarica Kochansky-Devidé \& Pantic: 21, pl. 3, figs 9-11; pl. 4, figs 1-10.

1966 Meandrospira sp.; Kochansky-Devidé \& Pantic: pl. 4, fig. 11.

For other synonymies before 1976, see Zaninetti (1976: 133) 1976 Meandrospira dinarica Kochansky-Devidé \& Pantic; Urosevic \& Dumurdanov: 93, pl. 2, figs 1, 2.

1977 Meandrospira dinarica Kochansky-Devidé \& Pantic; Pantic-Prodanovic \& Radosevic: 79, pl. 4, figs 1, 2.

1978 Meandrospira dinarica Kochansky-Devidé \& Pantic; Dager: 54, pl. 2, fig. 6 .
1983 Meandrospira dinarica Kochansky-Devidé \& Pantic; Salaj et al: 99 , pl. 47, fig. 4; pl. 51, figs 1-8; pl. 52, figs 1-8. 1983 Meandrospiranella (Kochansky-Devidé \& Pantic; 1966) n. sp.; Salaj et al.: 28 , fig. 8 .

1984 Meandrospira dinarica Kochansky-Devidé \& Pantic; He: 429, pl. 3, figs 4-6?, 7-9.

1986 Meandrospira dinarica Kochansky-Devidé \& Pantic; Sudar: pl. 19, figs 1-5.

1987 Meandrospira dinarica Kochansky-Devidé \& Pantic; Oravecz-Scheffer: 113, pl. 19, figs 1?, 2?, 3?, 4-11, 14.

1988 Meandrospira dinarica Kochansky-Devidé \& Pantic; Pirdeni: 1437, pl, 1, fig. 7.

1989 Meandrospira dinarica Kochansky-Devidé \& Pantic; Gaetani \& Gorza: pl. 10, fig. 2; pl. 1, fig. 5 (not named).

1990 Meandrospira dinarica Kochansky-Devidé \& Pantic; Baroz et al.: 30, pl. 5, figs 4-9.

1990 Meandrospira dinarica Kochansky-Devidé \& Pantic; Lualdi \& Bianchi: 48, fig. 10 (7).

Remarks. The Hydra specimens are close to the original description of the species, even though they are smaller in size (diameter of the test $0.20-0.35 \mathrm{~mm}$ ) than those figured by Kochansky-Devidé \& Pantic (1966). The specimen figured by Kochansky-Devidé \& Pantic (1966, pl. 4, fig. 11) and named Meandrospira sp. was distinguished by them because '. .die kleiner als die $M$. dinarica und mehr nautiloid ist, dünnere Wände und einen noch langsameren Zuwachs hat...' (1966: 27). The same specimen was considered by Salaj et al. (1983) to be a new species belonging to the genus Meandrospiranella Salaj, but they did not elaborate further in the text. In our view, this specimen is an axial cross-section of $M$. dinarica whose dimensions and morphology can be considered as intraspecific variation.

$M$. dinarica has been recorded in the Anisian of all Tethyan regions. In Hydra, $M$. dinarica occurs in the Early Anisian as high as the Pelsonian.

Occurrence. Gherakina, Eros Limestone s.s., section 3, samples H 60, H 66; Episkopi, Eros Limestone s.s., section 4, sample GL 342; O. Purgos, Eros Limestone s.s., section 5, samples H 125, H 126, H 127, H 128, GL 61, GL 58, GL 59, GL 60; O. Malies, Eros Limestone s.s., section 6, sample H 167; Tsingri Bay, Eros Limestone, upper lithozone, sample GL 155.

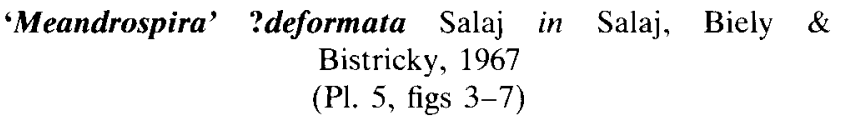

Remarks. In sample GL 334 we have found some specimens consisting of a globular proloculus and an undivided, tubular second chamber irregularly coiled; the wall is porcelaneous. These forms are very close to those

\section{Explanation of Plate 4}

Figs 1-4. Meandrospira dinarica Kochansky-Devidé \& Pantic, samples: figs 1, 2, H126, stratigraphic section 5; figs 3, 4, H127, stratigraphic section 5. Fig. 5a (left) Meandrospira dinarica Kochansky-Devidé \& Pantic; b (right) Endothanella wirzi Kohen-Zaninetti, sample: H178, Stratigraphic section 6. Figs 6-13. Meandrospira dinarica Kochansky-Devidé \& Pantic, samples: fig. 6, H128, stratigraphic section 5; fig. 7, H128, stratigraphic section 5; fig. 8, GL59, stratigraphic section 5; fig. 9, GL59, stratigraphic section 5; fig. 10, GL342, stratigraphic section 4; fig. 11, GL60, stratigraphic section 5; fig. 12, GL155, Eros Limestone, upper lithozone; fig. 13, GL155, Eros Limestone, upper lithozone. Fig. 14. Meandrospira pusilla (Ho), samplc: GL155, Eros Limestone, upper lithozone. Fig. 15. Meandrospira dinarica Kochansky-Devidé \& Pantic, sample: H60, stratigraphic section 3. 


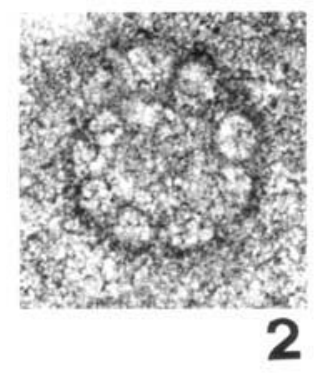

2

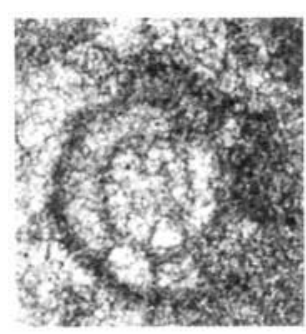

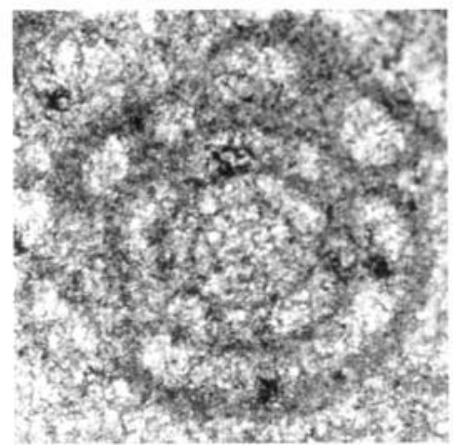

3

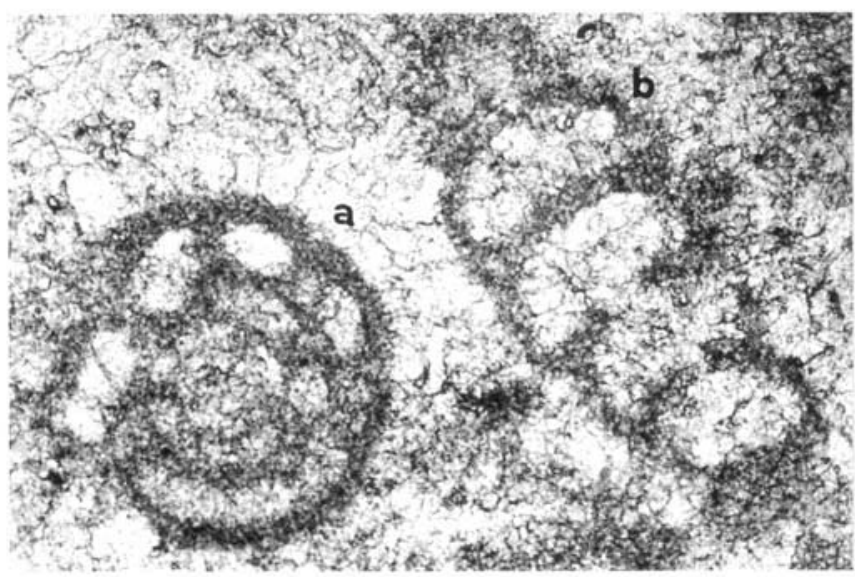

5
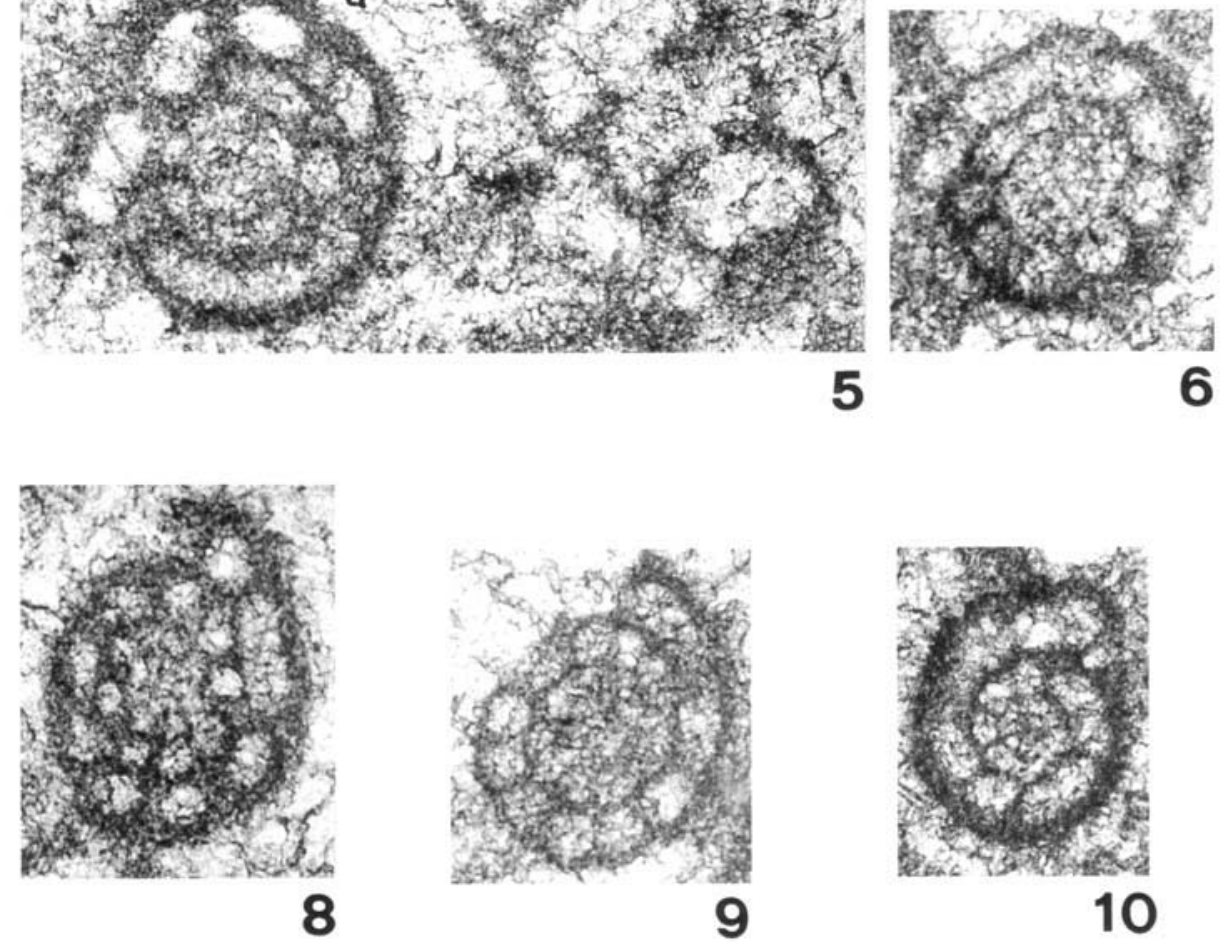

9

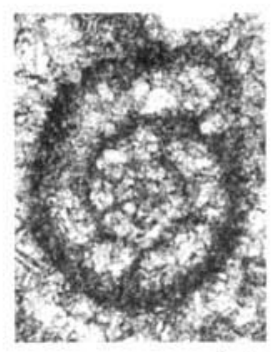

10

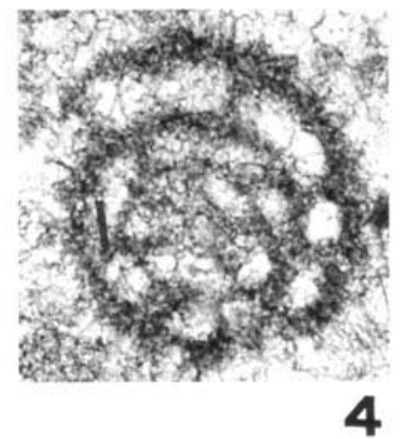

0 $250 \mu$

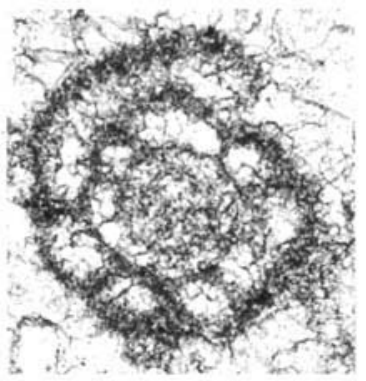

7

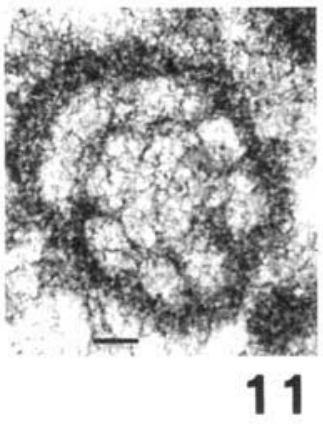

15

13
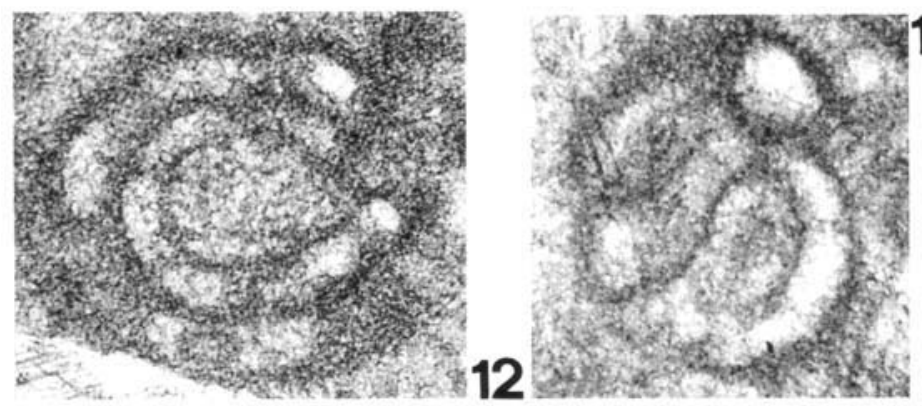

14

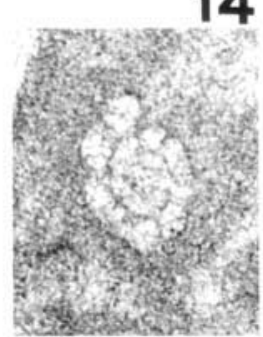

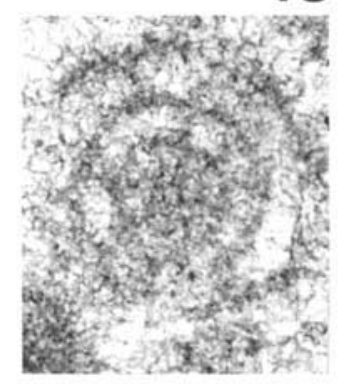


figured by Trifonova (1972, pl. 2, figs 4, 5) and Salaj et al. (1983, pl. 54, figs 1-6) and included in the taxon Meandrospira deformata Salaj, 1967 by them. Similar specimens have also been identified by Gazdzicki et al. (1975, pl. 7, figs 9-16) as Meandrospira? deformata Salaj. In our opinion all these specimens, including those from Hydra, do not correspond in shape and dimension to the holotype of Meandrospira deformata as figured originally by Salaj et al. (1967, pl. 2, fig. 3d) and by Salaj et al. (1983, pl. 53, fig. 4). The Hydra specimens were recorded near the base of the Pelsonian substage.

Occurrence. Between Episkopi and Aghios Marina, Eros Limestone s.s., section 4, sample GL 334.

\section{Genus Meandrospiranella Salaj, 1969 \\ Meandrospiranella? sp.}

(Pl. 5, figs 8-11; Pl. 6, fig. 1)

Remarks. Our specimens have been assigned to Meandrospiranella with reservation because only a slight tendency to uncoil can be observed. The Hydra species, at present left in open nomenclature, can be distinguished from Meandrospiranella samueli Salaj (in Salaj et al., 1967) in having a larger test $(0.55-0.6 \mathrm{~mm})$ and deuterolocular $(0.055-0.065 \mathrm{~mm}$ ) diameter (cf. also type material figured by Salaj, Borza \& Samuel, 1983, pl. 57, figs 1-5). Meandrospiranella? sp. has been recorded from Early Anisian to Pelsonian strata.

Occurrence. Episkopi, Eros Limestone s.s., section 4, sample Gl 342; O. Purgos, Eros Limestone s.s., section 5, samples H 125, H 126, H 127.

Subfamily Turriglomininae Zaninetti in Limongi et al., 1987

Genus Turriglomina Zaninetti in Limongi et al., 1987

Turriglomina mesotriasica (Koehn-Zaninetti, 1968)

(Pl. 6, fig. 3)

For synonymies before 1976, see Zaninetti (1976: 105).

1978a Turritellella? mesotriassica (sic) Koehn-Zaninetti; Trifonova: 101, pl. 2, fig. 11.

1978b Turritellella mesotriassica (sic) Koehn-Zaninetti; Trifonova: 58 , pl. 2 , fig. 1.

1978 'Turritellella' mesotriasica Koehn-Zaninetti; Dager: 50, pl. 1, figs 9, 10 .

1979 Turritellella mesotriasica Koehn-Zaninetti; He: 1169, pl. 73, fig. 6 .

1983 'Turritellella' mesotriasica Koehn-Zaninetti; Salaj et al.: 70 , pl. 16 , fig. 1 .

1985 Turritellella mesotriassica (sic) Koehn-Zaninetti; Sotak: 94, pl. 1, fig. 1.

1987 Turritellella mesotriasica Koehn-Zaninetti; OraveczScheffer: 111, pl. 16, figs 3, 7?.

1987 'Turritellella' mesotriasica Koehn-Zaninetti; OraveczScheffer: pl. 28, fig. 1; pl. 31, figs 1, 2, 5, 6?, 7 (not fig. 8).
1987 Turritellella mesotriasica Koehn-Zaninetti; He \& Yue: pl. 1, figs 16-22.

1987 Turritellella lataxis He \& Yue: pl. 2, figs 3-5, 13, 14. ?1987 Turritellella cf. mesotriasica Koehn-Zaninetti; He \& Yue: pl. 2, figs 1, 2.

1990 Turriglomina mesotriasica (Koehn-Zaninetti) (forme A?); Zaninetti et al:: pl. 1, fig. 12.

1990 Turritellella lataxis He \& Yue; He \& Wang: 224, pl. 2, figs $12,17,18$.

1991 Turriglomina mesotriasica (Koehn-Zaninetti): He \& Cai: 217 , pl. 2, figs 19, 20, 25.

Remarks. The specimens from Hydra correspond morphologically to the re-description given by Limongi et al. (1987). We now consider the Chinese species Turriglomina lataxis (He \& Yue, 1987) (=-Turritellella lataxis He \& Yue, 1987 ) to be synonymous with $T$. mesotriasica. In our opinion the specimens figured by He \& Yue (1987; pl. 2, figs 3-5, 13, 14, holotype fig. 4) and He \& Wang (1991; pl. 2, figs 12-17) are merely different cross-sections of $T$. mesotriasica. In fact, the diagnostic parameters of $T$. lataxis fall within the intraspecific variation of mesotriasica, as originally given by Koehn-Zaninetti.

$T$. mesotriasica is known from the Middle Triassic of many Tethyan regions (Zaninetti, 1976): the Balkans, Kocaeli Peninsula (Turkey), Carpathians (Czechoslovakia, Hungary), Southern Apennines (Italy), and Guangxi and Sichuan Provinces (China). In Hydra it has been found in association with an Illyrian conodont fauna characterized by $G$. excelsa and $G l$. tethydis (see above).

Occurrence. Vlichos, Han Bulog Limestone., sample H 4.

Turriglomina magna (Urosevic, 1981)

(Pl, 6, fig. 2)

1977 'Turritellella' mesotriasica Koehn-Zaninetti; Urosevic: pl. 1, figs 1-9, 10?, 11-15.

1981 Turritellella magna Urosevic: 114, pl. 2, figs 1-2

1987 Turriglomina mesotriasica (Koehn-Zaninetti); Limongi et al: 13 , figs $2 \mathrm{~A}, \mathrm{~B}$.

1987 Turriglomina mesotriasica (Koehn-Zaninetti), forme B, ou Turriglomina n. sp., ou Turriglomina n. sp. ou Turriglomina?; Zaninetti et al.: 177, pl. 1, fig. 2.

1988 Glomoturritellella magna (Urosevic); Urosevic: $377, \mathrm{pl}$. 2 , figs $1,1 \mathrm{a}-5$.

1990 Turriglomina magna (Urosevic); Ciarapica et al.: figs $4 \mathrm{~B}, \mathrm{C}$.

1990 cf. Turriglomina magna (Urosevic) (forme B?); Zaninetti et al:: 295, pl. 1, figs 4, 7,8?.

1990 Turriglomina magna (Urosevic) (forme B?); Zaninetti et al:: pl. 1, figs 5, 6 .

1990 cf. Turriglomina magna (Urosevic) (forme A?); Zaninetti et al.: pl. 1, figs 10-11.

1991 Turriglomina guangxiensis He in He \& Cai: 228, pl. 2, figs $15-18,21-24$; pl. 4 , figs $1-4,9$.

\section{Explanation of Plate 5}

Figs 1, 2. Meandrospira dinarica Kochansky-Devidé \& Pantic, sample: H66, stratigraphic scction 3. Figs 3-7. 'Meandrospira' ?deformata Salaj, sample: GL334, stratigraphic section 4. Figs 8-11. Meandrospiranella sp., samples: figs 8, 9, H125, stratigraphic section 5; fig. 10, H127, stratigraphic section $5 ;$ fig. 11 , H126, stratigraphic section 5 ; 

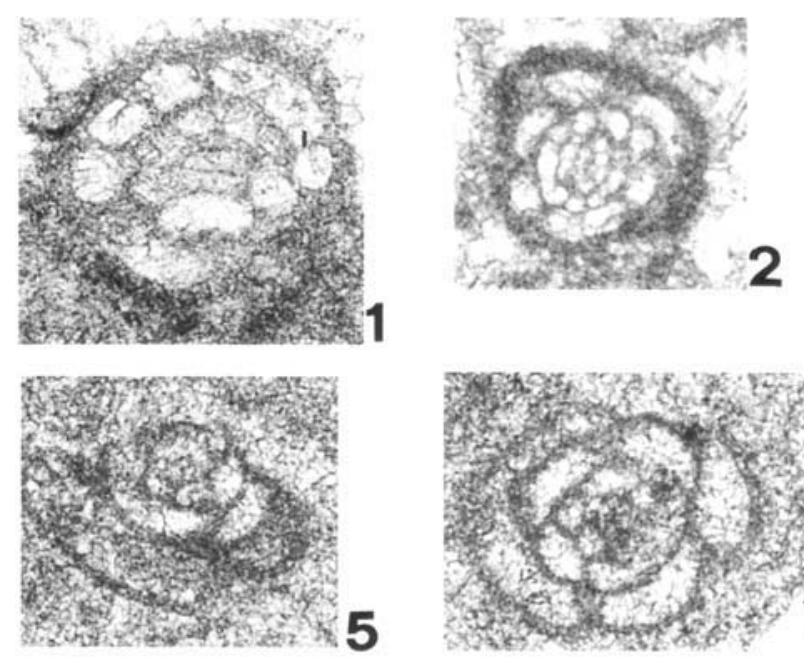
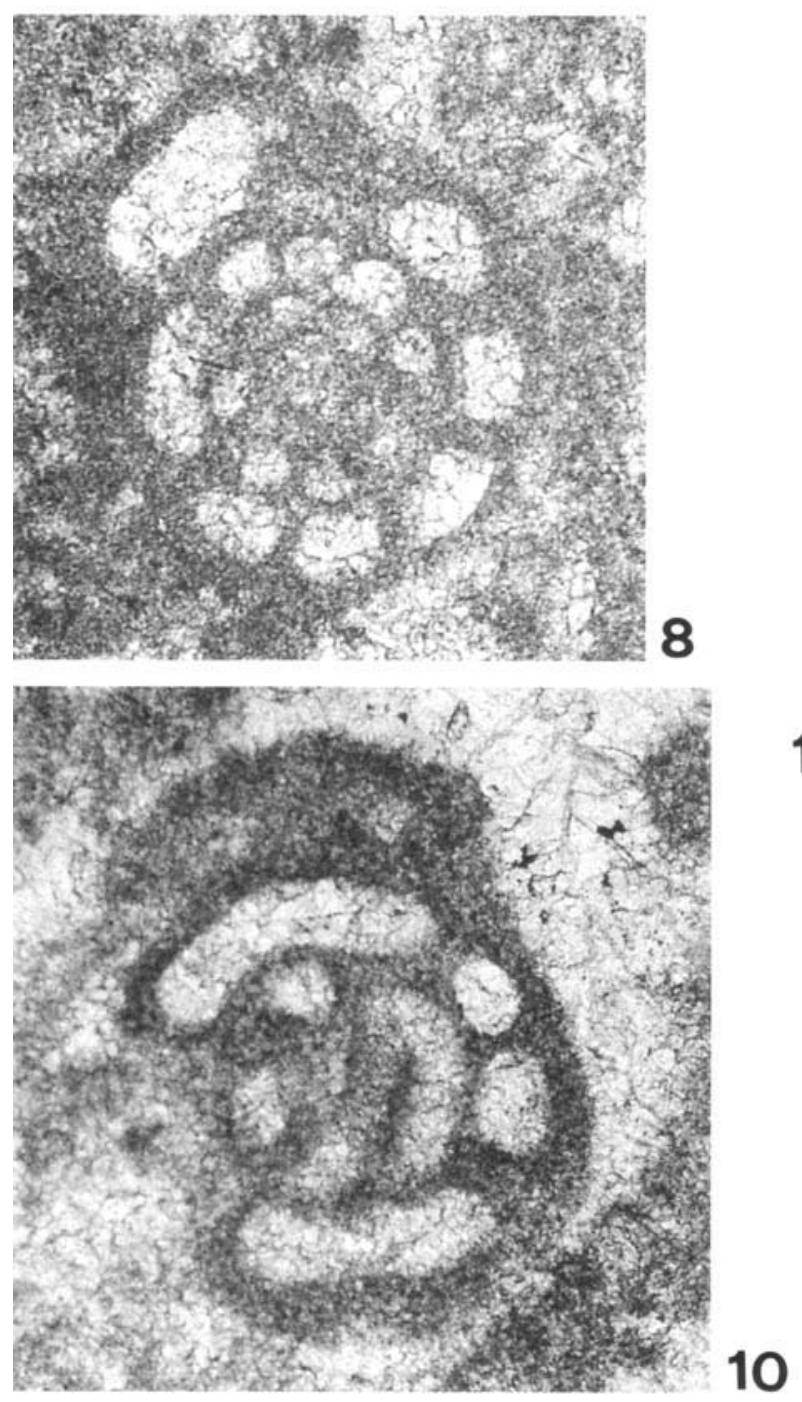
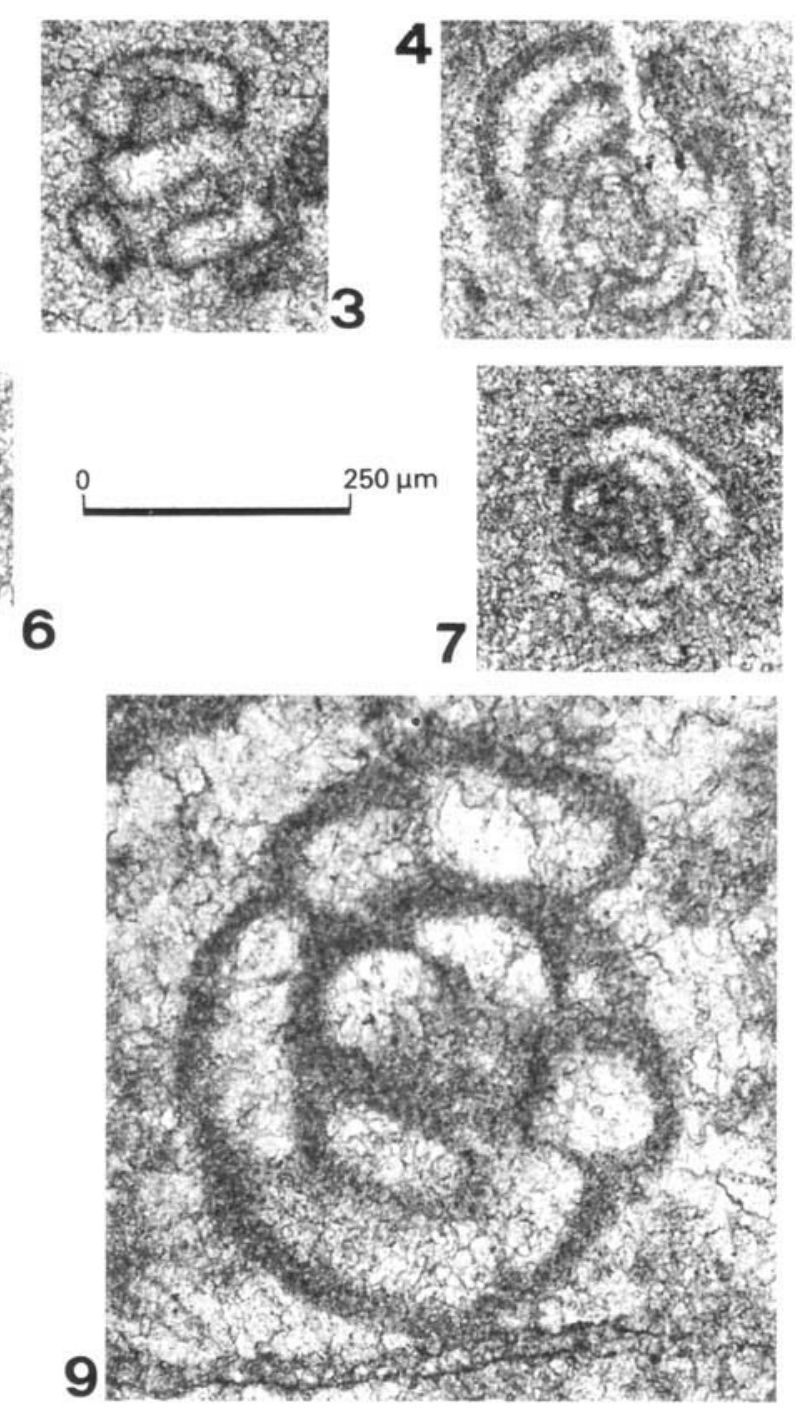

11

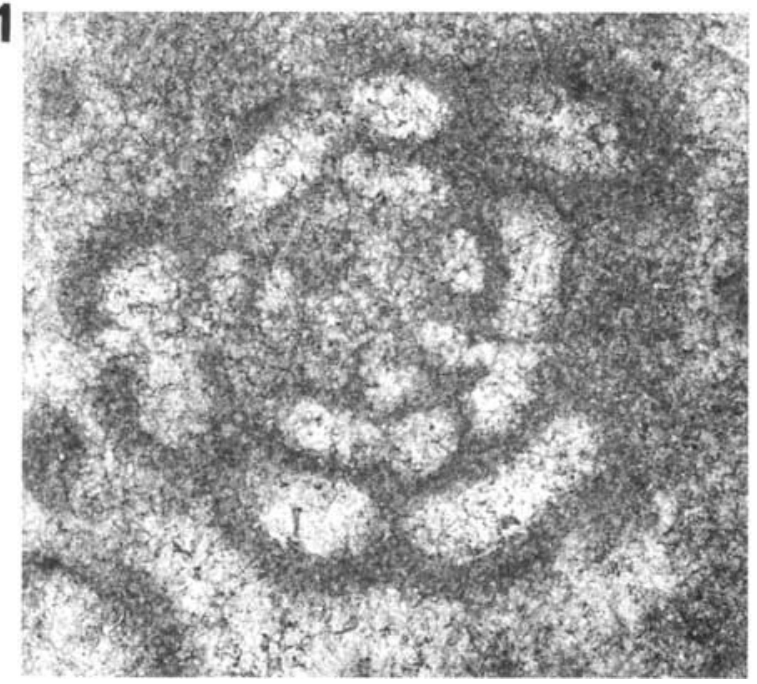


Remarks. Our specimen is morphologically (particularly dimensions, height $0.4 \mathrm{~mm}$ ) very similar to Turriglomina magna (Urosevic, 1981) $1=$ Glomoturitellella magna (Urosevic, 1981, 1988), originally recorded from the Carnian-Norian? limestones of the Balkans. Urosevic (1981) claimed to have observed the existence of dimorphism in this species, but the morphological differences of the two supposed generations are not clear. Neither we nor Zaninetti et al. (1990) could recognize dimorphism in our material, but can confirm the occurrence of the species in the Middle Triassic of Hydra and the Southern Apennines (M. Facito Formation auct.), respectively. In Hydra we have recorded it in the lower part of the Pelsonian.

The Chinese species Turriglomina guagxiensis He (in He \& Cai, 1991) is here considered to be a synonym of $T$. magna, since the morphology and the dimensional parameters are the same in the two species.

Occurrence. O. Purgos, Eros Limestone s.s., section 5, sample GL 57.

Superfamily Miliolacea Ehrenberg, 1839

Family Spiroloculinidae Wiesner, 1920

Genus Palaeomiliolina Antonova, 1959

Palaeomiliolina judicariensis (Premoli Silva, 1971)

(PI. 3, figs 5, 9)

1971 Agathammina judicariensis Premoli Silva: 343, pl. 29, figs $1,2,3,5,6$.

1975 Agathammina judicariensis Premoli Silva; Gazdzicki et al:: pl. 6, figs 1-2.

1976 Agathammina judicariensis Premoli Silva; Zaninetti: 132, pl. 5, figs 8,9 .

1977 Agathammina judicariensis Premoli Silva; Urosevic: pl. 2, figs $1-5$.

1979 Palaeomiliolina judicariensis (Premoli Silva); Trifonova: 9 , pl. 1 , figs $1-6$.

1987 Palaeomiliolina judicariensis (Premoli Silva); OraveczScheffer: pl. 15, fig. 14.

Remarks. In 1971 Premoli Silva described a new bilocular foraminifer coiled in about five planes (as in Quinqueloculina) and with two or three planispiral whorls, assigning this taxon to Agathammina Neumayr, 1887. Later, Trifonova (1979) referred this species to the genus Palaeomiliolina Antonova, 1959, because her new analysis demonstrated that it has chambers with a quinqueloculine coiling which sometimes have a tendency to a sigmoiline arrangement in the last whorls. The chamber arrangement of our specimens is in agreement with the generic placement of judicariensis within Palaeomiliolina as proposed by Trifonova (1979). According to Premoli Silva (1971), P. judicariensis appears in the Pelsonian at about the same time as the disappearance of Meandrospira dinarica (=Citaella dinarica in Premoli Silva, 1971). Trifonova found $P$. judicariensis in Pelsonian limestones in Bulgaria and Gazdzicki et al. (1975) and Oravecz-Scheffer also recorded the species in the Pelsonian (the Muschelkalk) of Poland and Hungary (Felsoör Limestone), respectively. In Hydra, $P$. judicariensis and $M$. dinarica occur at the same stratigraphical level in the Pelsonian substage; even if we have never found the two species in the same sample, it is possible that the two could coexist.

Occurrence. Episkopi, Eros Limestone s.s., section 4, sample GL346; O. Malies, Eros Limestone s.s., section 6, sample $\mathrm{H} 177$.

Suborder Spirillinina Hohenegger \& Piller, 1975

Family Spirillinidae Reuss \& Fritsch, 1861 Genus: Turrispirillina Cushman, 1927

Turrispirillina prealpina Zaninetti \& Brönnimann in Zaninetti, Brönnimann \& Baud, 1972a

(P1. 6, figs 6,7)

1972a Turrispirillina prealpina Zaninetti \& Brönnimann in Zaninetti, Brönnimann \& Baud: 480, pl. 6, figs 1-18; pl. 7, figs 4-7, 9, 10; pl. 9, figs 21, 22, 25-35; pl. 11, fig. 14.

1976 Turrispirillina prealpina Zaninetti \& Brönnimann; Zaninetti: 155 , pl. 14, figs 26-30.

1983 Turrispirillina prealpina Zaninetti \& Brönnimann; Salaj et al.: 131 , pl. 7 , fig. 1 .

Remarks. Our specimens are very similar to those described by Zaninetti et al., 1972a. The test is evolute with a high spire, but our cross-sections are always oblique, so that it is not possible to evaluate the exact apical angle, which however, appears to be fall within the same interval $\left(90-140^{\circ}\right)$ given by the original authors. The ratio of height versus basal diameter is about 1 , allowing $T$. prealpina to be distinguished from $T$. minima Pantic, whose ratio ranges from $1: 2$ to $2: 3$. The distinction between these two species is also based on the fact that, in section, the deuteroloculus of $T$. minima is not as circular as that of $T$. prealpina and the coiling is semi-involute.

The calcareous hyaline wall of $T$. prealpina is not well preserved in our material, because of the presence of an encrusted surface.

According to Zaninetti et al. (1972a,b), T. prealpina occurs in the late Anisian of the Swiss Prealps. In Hydra, it occurs in Early Anisian to Pelsonian strata.

Occurrence. O. Purgos, Eros Limestone s.s., section 5, samples GL 60, H 127.

Superfamily Involutinacea Bütschli, 1880

Family Triadodiscidae Zaninetti, 1984 or

Aulotortidae Zaninetti, 1984

Subfamily Triadodiscinae Zaninetti, 1984 or Aulotortinae Zaninetti, 1984

Explanation of Plate 6

Fig. 1. Meandrospiranella sp., sample: GL342, stratigraphic section 4. Fig. 2. Turriglomina magna (Urosevic), sample: GL57, stratigraphic section 5. Fig. 3. Turriglomina mesotriasica (Koehn-Zaninetti), sample: H4, Han Bulog Limestone, Vlichos. Figs 4, 5. Spirillina sp., sample: GL60, stratigraphic section 5. Figs 6, 7. Turrispirillina prealpina Zaninetti \& Brönnimann, samples: fig. 6: GL60, stratigraphic section 5; 7, H127, stratigraphic section 5. Fig. 8. Triadodiscus or Aulotortus n.sp., sample: H185, stratigraphic section 6. (The vertical scale refers to fig. 8). Fig. 9. ?Lamelliconus sp., sample: GL60, stratigraphic section 5. Fig. 10. Triadodiscidae or Aulotortidae, sample: GL61, stratigraphic section 5. 

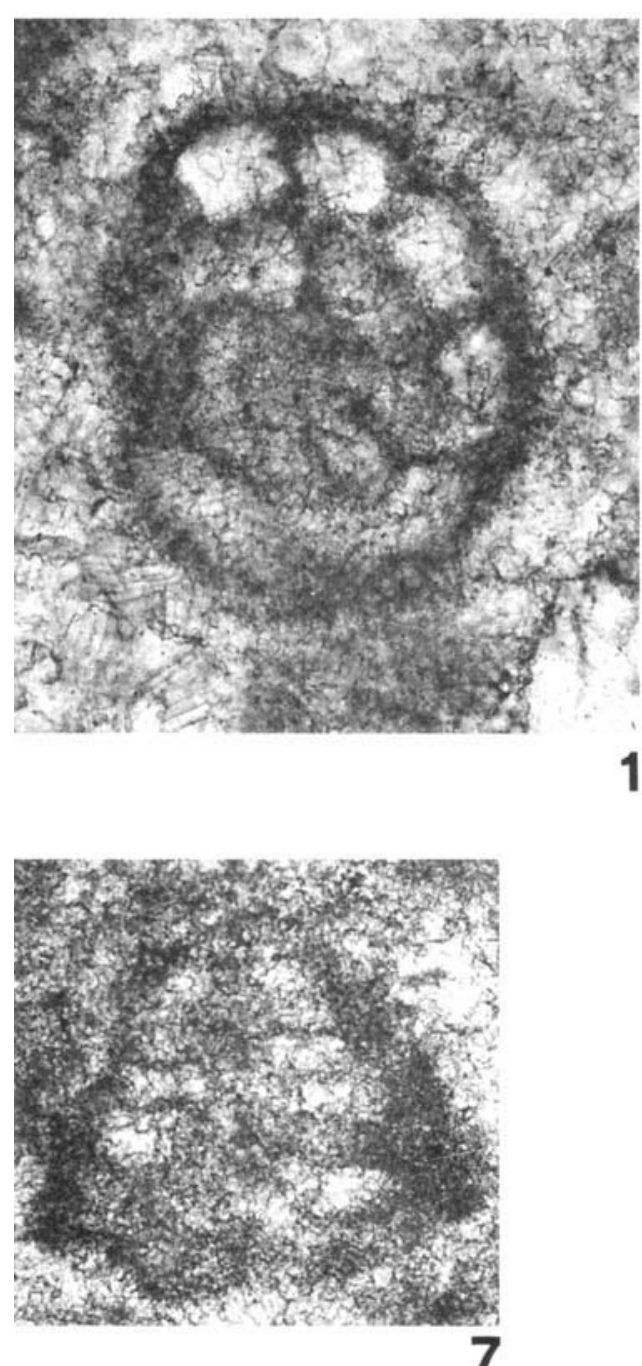

0 $250 \mu \mathrm{m}$
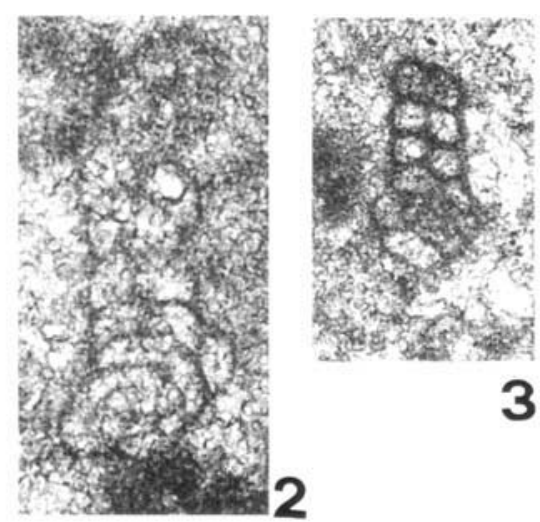

3
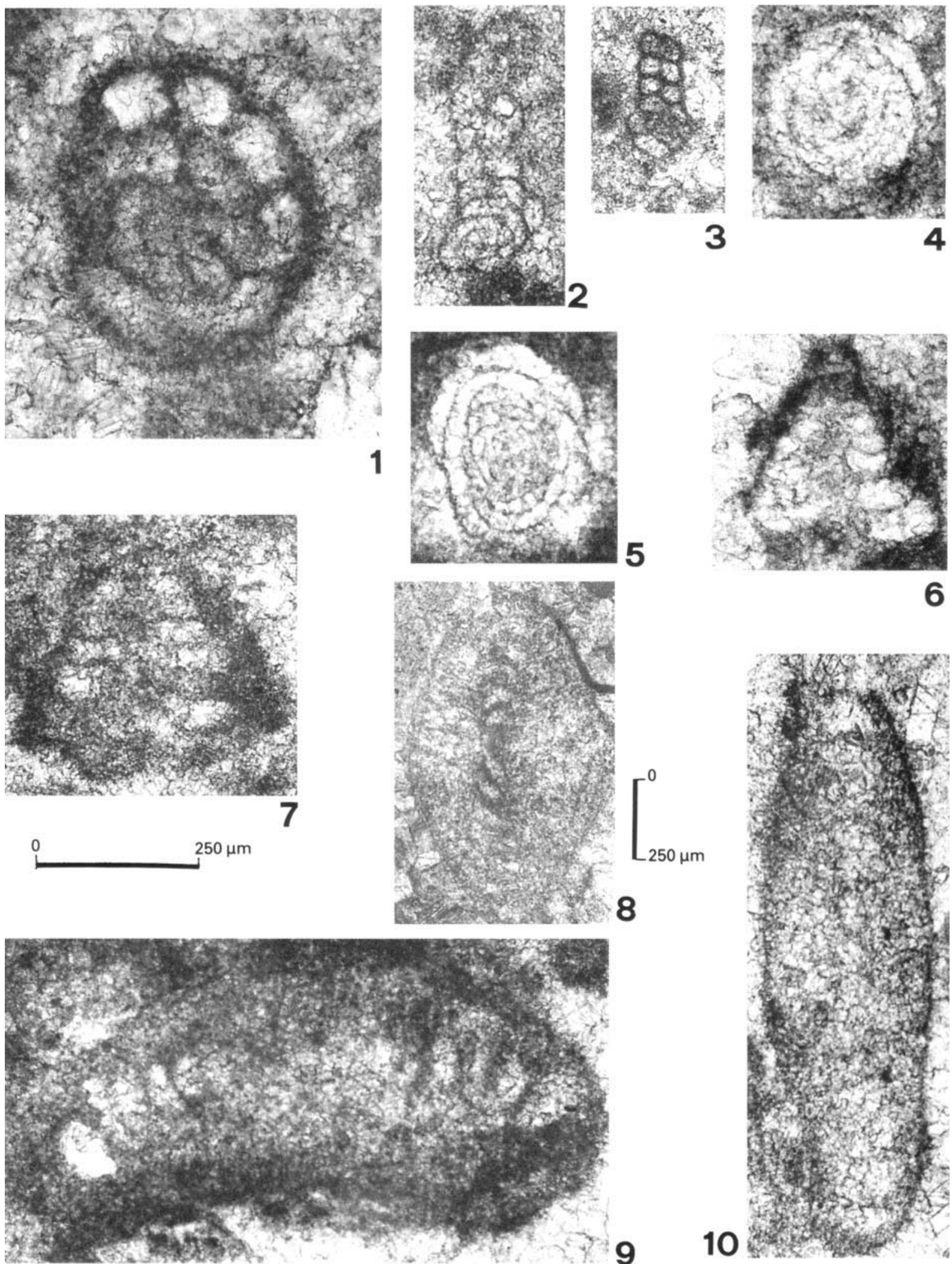

9

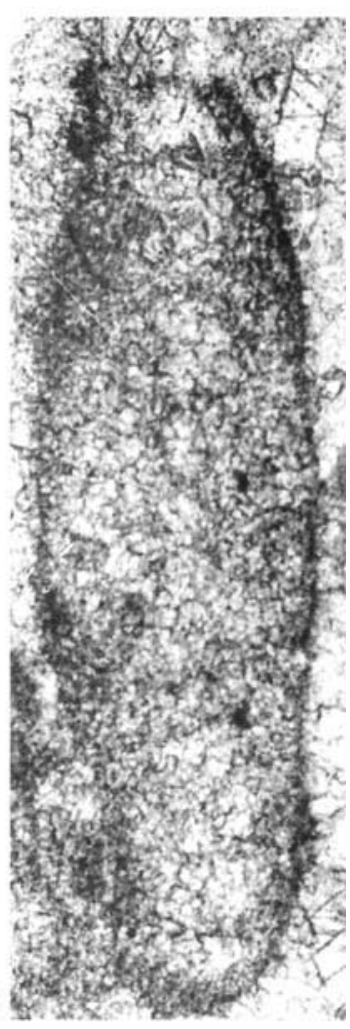




\section{Genus Triadodiscus Piller, 1983 or Aulotortus \\ Weynschenk, 1956 \\ Triadodiscus or Aulortortus n. sp.}

$$
\text { (Pl. 6, fig. 8) }
$$

1973a Involutina sinuosa pragsoides (Oberhauser); Brönnimann et al.: 315 , pl. 19, figs 1-18; pl. 20, figs 1-7, 9, 10, 13; fig. 1a-t.

1975 Involutina sinuosa pragsoides (Oberhauser); Gazdzicki et al.: pl. 10, fig. 9.

Remarks. The specimens from Hydra are like those figured by Brönnimann et al. (1973a) from the Anisian of Bosnia-Herzegovina and named by them as Involutina sinuosa pragsoides (Oberhauser). In our opinion, the new species can be distinguished from $I$. sinuosa pragsoides in having much larger test diameter $(1.1 \mathrm{~mm})$, a very small diameter of the deuteroloculus $(0.05 \mathrm{~mm}$ in the early whorls) and a marked peculiar rhomboid shape. A detailed revision of the material by Brönnimann, Cadet \& Zaninetti (1973a) is necessary before this species can formally be described and assigned to the correct genus.

It is also present in the Pelsonian Muschelkalk of Southern Poland (Gazdzicki et al., 1975); in Hydra, on the basis of the presence of the conodonts $G . b$. bifurcata, $G . b$. hanbulogi and $G$. bulgarica, its occurrence is Late Pelsonian in age.

Occurrence. O. Malies, Eros Limestone, upper lithozone, section 6 , sample $\mathrm{H} 185$.

\section{Superfamily Duostominacea Brotzen, 1963 \\ Family Duostominidae Brotzen, 1963 \\ Genus Krikoumbilica He, 1984 \\ Krikoumbilica pileiformis He, 1984}

(Pl. 1, fig. 5)

1973a Duostominidae: Diplotremina? sp. Kristan-Tollmann; Brönnimann et al: pl. 21, figs 14, ?16.

1975 Diplotremina astrofimbriata Kristan-Tollmann; Gazdzicki et al: pl. 6, figs 4, 5?,6.

1984 Krikoumbilica pileiformis $\mathrm{He}$ : 430, pl. 2, figs 9, 10, 12, 13; pl. 4, figs 8-11 (also recorded as pileformis on p. 430).

1991 Krikoumbilica pileiformis $\mathrm{He}$; $\mathrm{He} \&$ Cai: pl. 2, figs 1, 2, 3,5 ?, 6; pl. 4, figs 8, 11 ?.

Remarks. The specimen illustrated by us is very similar to the holotype illustrated by $\mathrm{He}$ (1984). The species is characterized by a circular umbilicus, whose margin is not lobate like that in Diplotremina Kristan-Tolmann.

Loeblich \& Tappan (1987) assigned the Genus Krikoumbilica to the family Oberhauserellidae Fuchs, but the wall of Krikoumbilica is calcareous microgranula while that of the Oberhauserellidae is calcareous hyaline. According to Koehn-Zaninetti (1969), the Anisian specimens of the Duostominidae usually exhibit one microgranular calcitic layer, which represents the outer preserved layer of the double wall of the test; this is also confirmed by Premoli Silva (1971). We therefore agree with the assignment of $K$. pileiformis by He (1984: 426) to the Duostominidae.

He (1984) discovered $K$. pileiformis in the Middle Triassic Qingyan Formation and Yangliujing Limestone of southern Guizhou, China. All the other citations in our synonymy are Middle Triassic in age and were recorded in the
Muschelkalk of southern Poland (Gazdzicki et al., 1975) and in the Anisian reefal limestones of Bosnia-Herzegovina (Brönnimann et al., 1973a). In Hydra it is recorded for the first time from the Scythian on the basis of the presence of the conodont Neospathodus homeri (Bender) in the same sample.

Occurrence. O. Purgos, Eros Limestone s.s., section 5, sample H 103.

\section{Lituolidae of uncertain generic classification}

(Pl. 3, figs 4, 7-8)

In our material there are several sections of foraminifera with agglutinated or microgranula walls, often large in size. These have been assigned to Ammobaculites sp./Reophax $\mathrm{sp}$. as their cross-sections do not show the initial part, which could be planispiral or uniserial. Sometimes in the literature, authors (i.e. Premoli Silva, 1971; Salaj et al., 1983, Oravecz-Scheffer, 1987; Trifonova, 1992) have assigned these specimens to Earlandinita. We do not agree with this assignment because the initial spire, which is the main diagnostic character used to distinguish the different genera, is never recognizable.

\section{ACKNOWLEDGEMENTS}

The authors are deeply grateful to A. Nicora (University of Milan) for the conodont determinations and for her friendship. Special thanks are due to $L$. Zaninetti (University of Geneva), M. Gaetani and I. Premoli Silva (University of Milan) for their interest and their constructive criticism. J. E. Whittaker (British Museum (Natural History), London gave assistance and reviewed the manuscript.

\section{Manuscript received September 1992 \\ Revised manuscript accepted April 1993}

\section{REFERENCES}

Angiolini, L., Dragonetti, L., Muttoni, G. \& Nicora, A. 1992. Triassic stratigraphy in the Island of Hydra (Greece). Rivista Italiana di Paleontologiae Stratigrafia, 98: 137--180.

Baroz, F., Martini, R. \& Zaninetti, L. 1990. Un aspect de la plate-forme carbonatée triasique dans les hellénides internes: le chaînon d'Orékastro. Rivista Italiana di Paleontologiae Stratigrafia, 96: 21-38.

Bechstädt, T. \& Bradner, R. 1970. Das Anis zwicschen St. Vigil und dem Hölensteintal (Pragser und Olanger Dolomiten, Südtirol). Festband, Geologische Institut, 300-Jahr-Feier der Universität Innsbruck, 9-103

Brönnimann, P., Cadet, J. P. \& Zaninetti, L. 1973a. Sur la présence d'Involutina sinuosa pragsoides (Oberhauser) (Foraminifère) dans l'Anisien supérieur probable de Bosnie-Herzégovine méridionale (Yougoslavie). Rivista Italiana di Paleontologiae Stratigrafia, 79: 301-336.

Brönnimann, P., Cadet, J. P. \& Zaninetti, L. 1973b. Sur quelques Foraminifères de l'anisien (Trias moyen) de Bosnie-Herzégovine méridionale (Yougoslavie). Rivista Italiana di Paleontologiae Stratigrafia, 79: 461-478.

Ciarapica, G., Cirilli, S., Martini, R., Rettori, R., Zaninetti, L. \& Salvini-Bonnard, G. 1990. Carbonate buildups and associated facies in the Monte Facito Formation (Southern Apennines). Bollettino della Società Geologica Italiana, 109: 151-164.

Dager, Z. 1978. Les foraminiferes du Trias de la Péninsule de Kocaeli-Turquic. Notes du Laboratoire Paléontologique Université de Genève, 3(4): 23-71. 
Efimova, N. A. 1974. Triassic foraminifera of the North-West Caucasus and Cis-Caucasus. Akademii Nauk CCCP, 17: 54-83.

Farabegoli, E., Pisa, G. \& Ott, E. 1976. Risultati preliminari sull'Anisico della Conca di Agordo e dell'Alta Val di Zoldo (Dolomiti Sudorientali). Bollettino della Società Geologica Italiana, 95: 659-703.

Gaetani, M. \& Gorza, M. 1989. The Anisian (Middle Triassic), carbonate bank of Camorelli (Lombardy, Southern Alps). Facies, 21: $9-13$.

Gazdzicki, A. \& Smit, O. E. 1977. Triassic foraminifers from the Malay Peninsula. Acta Geologica Polonica, 27: 319-332.

Gazdzicki, A., Trammer, J. \& Zawidzka, K. 1975. Foraminifers from the Muschelkalk of Southern Poland. Acta Geologica Polonica, 25: 285-298.

Harland, W. B., Armstrong, R. L., Cox, A. W., Craig, L. E., Smith, A. (j. \& Smith, D. G. 1990. A geologic time scale 1989. Cambridge University Press, Cambridge, 263pp.

He. 1979. Sketch of the Triassic foraminiferal biostratigraphy of northwestern Sichuan (Szechuan), China. Rivista Italiana di Paleontologiae Stratigrafia, 85: 1167-1174.

He. 1984. Middle Triassic foraminifera from the central and southern Guizhou, China. Acta Palaeontologica Sinica, 23: $420-431$.

He. 1988. Early and Middle Triassic foraminifera from Jiangsu and Anhui Provinces, China. Acta Micropalaeontologica Sinica, 5: $85-92$.

He \& Cai. 1991. Middle Triassic foraminifera from Tiandong Depression, Baise Basin, Guangxi, China. Acta Palaeontologica Sinica. 30: 212-230.

$\mathrm{Hc} \&$ Wang. 1991. Triassic foraminifera from Yushu region, Qinghai. In Devonian-Triassic stratigraphy and palaeontology from Yushu region of Qinghai, China, 55-95, Nanjing University Press.

He \& Yue. 1987. Triassic foraminifera from Maatang of Jiangyou, Sichuan, China. Bulletin of the Nanjing Institute of Geology \& Palaeontology, Academia Sinica, 12: 191-230.

Ho. 1959. Triassic Foraminifera from the Chialingkiang Limestone of South Szechuan. Acta Palaeontologica Sinica, 7: 387-418.

Jacobshagen, V., Martz, J. \& Reinhardt, R. 1977. Eine alttertiare Ophiolith-Decke in den inneren Helleniden NE-Griechenlands. Neues Jahrbuch für Geologie und Paläontologie, 1977: 613-620.

Kochansky-Devidé, V. \& Pantic, S. 1966. Meandrospira in der Unteren und Mittleren Trias sowie einige begleitende Fossilien in den Dinariden. Geoloski Viesnik, 19: 15-28.

Koehn-Zaninetti, L. 1968. Les Foraminifères du Trias de la région de l'Almtal (Haute-Autriche). Texte condensé de la thèse No. 1467, Ed. Médicine et Hygiène, Genève, $14 \mathrm{pp}$.

Koehn-Zaninctti, L. 1969. Les Foraminiféres du Trias de la région de l'Almtal (Haute-Autriche). Jahrbuch der Geologischen Bundesanstalt, Sonderband, 14: 1-155.

Limongi, P., Panzanelli-Fratoni, R., Ciarapica, G., Cirilli, S., Martini, R., Salvini-Bonnard, G. \& Zaninetti, L. 1987. Turriglomina Zaninetti, n. gen., un nouveau nom pour "Turritellella" mesotriasica Kochn-Zaninetti, 1968 (Foraminifere, Trias Moyen). Archives des Sciences Genève, 40: 13-22.

Loeblich, A. R. \& Tappan, H. 1987. Foraminiferal genera and their classification. Van Nostrand Reinhold Company Inc., New York.

Lualdi, A. \& Bianchi, U. 1990. La formazione di Costa Losera: una nuova unita' stratigrafica nell'Anisico delle Alpi Liguri (Brianzonese e Prepiemontese). Atti Ticin. di Scienze della Terra, 33: $33-62$.

Mietto, P., Panzanelli Fratoni, R. \& Perri, C. 1991. Spathian and Aegean conodonts from the Capelluzzo calcarenites of the Monte Facito Group (Lagonegro sequence-Southern Apennines). Memorie degli Istituto di Geologia e Mineralogia dell Università di Padova, 43: 305-317.

Mountrakis, D., Patras, D., Kilias, A., Pavlides, S. \& Spyropoulos, N. 1987. Structural geology of the Internal Hellenides and their role to the geotectonic evolution of the Eastern Mediterranean. Acta Naturalisti dell Ateneo Parmense, 23: 142-172.

Oravec-Scheffer, A. 1987. Triassic foraminifers of the Transdanu- bian Central Range. Geologica Hungarica (Palaeontologica), 50: $1-331$.

Pantic, S. 1965. Pilammina densa, n.gen., n.sp. and other Ammodiscidae from the Middle Triassic in Crmnice (Montenegro). Geoloski Vjesnik, 18 (for 1984): 189-193.

Pantic-Prodanovic, S. \& Radosevic, B. 1977. Geological section of Scythian and Anisian stages in the Jelovica River Valley (Southern Serbia). Bulletin Muséum d'Histoire Naturelle. Beograd, 32: 75-95.

Pirdeni, A. 1988. The Triassic foraminifera of Albania. Revue de Paléobiologie, Volume Speciale 2 (Benthos '86): 145-152.

Premoli Silva, I. 1964. Citaella iulia n.gen., n.sp. del Trias inferiore della Carnia. Rivista ltaliana di Paleontologiae Stratigrafia, 70: $657-670$.

Premoli Silva, I. 1971. Foraminiferi anisici della regione giudicariense (Trento). Rivista ltaliana di Paleontologia e Stratigrafia, 77: 303-374.

Ramovs, A. 1972. Mikrofauna der alpine und voralpine Trias Sloweniens. Mitteilungen der Gesellschaft der Geologie und Bergbaustuden, 21: 413-426.

Renz, C. 1906. Trias und Jura in der Argolis. Zeitschrift der Deutschen Geologischen Gesellschaft, Berlin, 58: 379-395.

Renz, C. 1910. Stratigraphische Untersuchungen im griechischen Mesozoikum und Palozoikum. Jahrbuch der KaiserlichKöninglichen Geologischen Reichsanstalt, 60: 421-636.

Renz, C. 1925. Zur Geologie der Insel Hydra. Eclogae Geologicae Helvetiae, 19: 363-372.

Renz, C. 1931. Die Bulogkalke der Insel Hydra (Ostpeloponnes). Eclogae Geologicae Helvetiae, 24: 53-60.

Römermann, H. 1968. Geologie von Hydra (Griechenland). Geologica et Palaeontologica, 2: 163-171.

Römermann, H., Graf, W., Huckreide, P., Jacobshagen, V., Kahler, F.. Walliser, H., Zapfe, H. \& Bornovas, J. 1981. Hydra: Geological Map, 1:50,000 scale. Geological Survey of Greece, I.G.M.E., Athens.

Salaj, J. 1969. Essai de zonations dans le Trias des Carpates occidentales d'apres les foraminifères. Geologické Práce, 48: $123-128$.

Salaj, J., Biely, A. \& Bistricky, J. 1967. Trias-Foraminiferen in den Westkarpaten. Geologické Práce, 42: 119-136.

Salaj, J., Borza, K. \& Samuel, O. 1983. Triassic foraminifera of the West Carpathians. Geologický Ústav Dionýza Štúra, Bratislava.

Salaj, J., Trifonova, E. \& Gheorghian, D. 1988. A biostratigraphic zonation based on benthic foraminifera in the Triassic deposits of the Carpatho-Balkans. Revue de Paléobiologie, Volume Speciale 2 (Benthos '86): 153-159.

Schäfer, P. \& Senowbari-Daryan, M. 1984. The Upper Triassic Pantokrator Limestone of Hydra, Greece: An example of a prograding recf complex. Facies, 6: 147-164.

Sudar, M. 1986. Triassic microfossil and biostratigraphy of the inner Dinarids between Gucevo and Lyubisnya Mts.; Yugoslavia. Geološki Anali Balkanskoga Poluostrva, 50: 1-394.

Trifonova, E. 1972. Triassic forminifera in north Bulgaria. Mitteilungen Gesellschaft der Geologie und Berghaustudenten, 21: 15-34.

Trifonova, E. 1977. Foraminifera from the Upper Scythian in Northeastern Bulgaria. Palaeontologiya, Stratigrafiya i Litologiya, Bulgarska Akademiya na Naukite, 7: 15-34.

Trifonova, E. 1978a. The foraminifera zones and subzones of the Triassic in Bulgaria. 1. Scythian and Anisian. Geologica Balkanica, 8(3): 85-104.

Trifonova, E. 1978b. The foraminifera zones and subzones of the Triassic in Bulgaria. 2. Ladinian and Carnian. Geologica Balkanica, 8(4): 49-64.

Trifonova, E. 1979. On the generic status of Agathammina judicariensis Pr.-Silva, 1971 (Foraminifera). Palaeontologiya, Stratigryfiya y Litologiya, Bulgarska Akademiya na Naukite, 10: 9-10.

Trifonova, E. \& Catalov, G. A. 1988. Foraminifera data on the stratigraphy of the Strandza facial type of Triassic (Strandza Mt. SE Bulgaria). Geologica Balkanica, 18(5): 79-84.

Trifonova, E. 1992. Taxonomy of Bulgarian Triassic foraminifera. 1. 
Families Psammospheraeridac to Nodosinellidac. Geologica Balkanica, 22(1): 3-50.

Urosevic, D. 1977. Stratigraphic position of some foraminifers in Triassic sediments of the Carpatho-Balkanides. Geoloski Anali Balkanskoga Poluostrva, 41: 227-231.

Urosevic, D. 1981 Some new species from the Triassic of East Serbia (the Carpatho-Balkanides). Zapisnici Srpskog Geoloskog Drfustua, 56 (for 1980): 113-118.

Urosevic, D. 1988. Microfossils from the Triassic of the Inner Belt of the Yugoslavian Carpatho-Balkanides. Geoloski Anali Balkanskogo Poluostrva, 52: 371-379.

Vachard, D. \& Razgallah, S. 1988. Importance phylogénćtique d'un noveau Foraminifér Endothyroide: Endoteba controversa n.gen., n.sp; (Permien du Jebel Tebaga, Tunisie). Geobios, 21: 805-811.

Zaninetti, L. 1976. Les Foraminifères du Trias. Rivista Italiano di Paleontologia, 82: 1-258.

Zaninctti, L., Brönnimann, P. \& Baud, A. 1972a. Microfacies particuliers et foraminifères nouveaux de l'Anisien superier de la coupe du Rothorn (Préalpes médianes rigides, Diemtigtal. Suisse). Mitteilungen Gesellschaft der Geologie und Bergbaustudenten, 21: 465-498.

Zaninetti, L., Brönnimann, P. \& Baud, A. 1972b. Essai de zonation d'après les foraminifères dans l'Ansien moyen et supérieur des Préalpes médianes rigides (Préalpes romandes, Suisse, et Préalpes du Chablais, France). Eclogae Geologicae Helvetiae, 65: 343-353.

Zaninetti, L., Ciarapica, G., Martini, R., Salvini-Bonnard, G. \& Rettori, R. 1987. Turriglomina scandonei n.sp., dans les calcaires recifaux du Trias Moyen (Ladinien) en Apennin meridional. Revue de Paléobiologie, 6: 177-182.

Zaninetti, L., Ciarapica, G., Martini, R. \& Rettori, R. 1990. Paléoécologie des Turriglomines (Foraminifères) dans le trias de l'Apennin méridional (Bassin de Lagonegro) Italie. Archives des Sciences, Genève, 43: 295-305. 